Volumen XX, número 1, enero-junio de 2020.

Recibido: 29 de octubre de 2019. Aprobado: 6 de abril de 2020.

\title{
¿Una peregrinación extranjera? Espacialidad y estrategias identitarias del colectivo boliviano en Argentina*
}

\section{A foreign pilgrimage? Spatiality and identity strategies of the Bolivian community in Argentina}

\author{
Carlos Luciano Dawidiuk**
}

Carolina Vogel***

Universidad Nacional de Luján, Argentina

\begin{abstract}
Resumen
La colectividad boliviana en Argentina celebra a la Virgen de Copacabana movilizándose hacia la ciudad de Luján, el centro de peregrinación más grande del país, cada primer fin de semana del mes de agosto desde hace más de sesenta años. La circulación de múltiples símbolos de reivindicación y reafirmación identitarias de este colectivo, como así también sus músicas y danzas, que manifiestan mediante diversas prácticas corporales esta pertenencia, imprimen a esta celebración un carácter distintivo respecto a otras

* Este artículo es producto del trabajo realizado en el marco del proyecto de investigación "Cartografías sociales de lo sagrado: territorios, fiestas religiosas y paisajes peregrinos (II Parte)", radicado en la Secretaría de Investigaciones, División Investigación, Posgrado y Transferencia, Departamento de Ciencias Sociales, Universidad Nacional de Luján. Director: Dr. Fabián Claudio Flores; codirectora: Dra. Cristina Teresa Carballo. Período: enero 2018-diciembre 2019. Disposición DISPCD-CSLUJ: 0000760/17.

** Profesor y licenciado en Historia, Universidad Nacional de Luján, Argentina. Docente e investigador, Grupo Interdisciplinario de Estudios sobre Paisaje, Espacio y Cultura, Departamento de Ciencias Sociales, Universidad Nacional de Luján. Correo electrónico: luchodawidiuk@ yahoo.com.ar

*** Licenciada en Ciencias Sociales y Humanidades, Universidad Nacional de Quilmes, Argentina. Investigadora, Grupo Interdisciplinario de Estudios sobre Paisaje, Espacio y Cultura, Departamento de Ciencias Sociales, Universidad Nacional de Luján. Correo electrónico: carolinavogel@ yahoo.com.ar.
\end{abstract}

Cómo citar este artículo: Dawidiuk, C. y Vogel, C. (2020). ¿Una peregrinación extranjera? Espacialidad y estrategias identitarias del colectivo boliviano en Argentina. Si Somos Americanos. Revista de Estudios Transfronterizos, 20(1), 123-151. doi: 10.4067/S0719-09482020000100123 
manifestaciones que históricamente han tenido como epicentro a esta ciudad. Pero su denominación como "peregrinación boliviana" entraña una representación identitaria y del ritual religioso que no da cuenta de la hibridez de este fenómeno, en el que tanto los símbolos, las prácticas y los participantes exceden la caracterización de esta manifestación como extranjera. Así, nos proponemos indagar y analizar las estrategias identitarias transculturales y transmediales en el escenario móvil de la peregrinación, los modos en que se articulan y despliegan esos discursos -símbolos y prácticas desterritorializados y reterritorializados en un espacio-movimiento heterotópico- que interpelan los límites entre los espacios sagrados y profanos reactualizando en el ritual aspectos de la memoria histórica que permiten resignificar los vínculos entre la identidad y el territorio.

Palabras clave: peregrinación, espacio urbano, identidad cultural.

\begin{abstract}
The Bolivian community in Argentina celebrates the Virgin of Copacabana by travelling to the city of Luján, the country's largest center of pilgrimage. During the first weekend of August, the faithful engage in a tradition that dates back over 60 years. The circulation of multiple symbols is linked to identity claims and the reaffirmation of this community, as well as their music and dance. All of these elements reveal a sense of belonging that is expressed through various corporal practices. The combination of these practices distinguishes this celebration from the other practices that have developed in this city over the years. However, the practice of calling it a 'Bolivian pilgrimage' implies a representation of identity and religious ritual that does not reflect the 'hybridity' of this phenomenon. In fact, the symbols, practices and participants go beyond the characterization of this manifestation as being 'foreign'. The aim of this article is thus to explore and analyze the transcultural and transmedial identity strategies in the 'mobile setting' of the pilgrimage. The authors consider how such discourses, symbols and practices are expressed and deployed and de-territorialized and re-territorialized in a heterotopic space-movement. The result is an analysis that questions the boundaries between sacred and profane spaces, re-actualizing in the ritual those aspects of historical memory that allow us to re-signify the links between identity and territory.
\end{abstract}

Keywords: pilgrimage, urban space, cultural identity.

\title{
Introducción
}

En este trabajo nos proponemos observar y analizar las estrategias identitarias desplegadas por el colectivo boliviano en la peregrinación de la Virgen de Copacabana a Luján. Para 
ello nos hemos valido fundamentalmente de la observación participante, realizando entrevistas a una amplia gama de actores (bailarines, músicos, sacerdotes, espectadores, organizadores, pasantes, entre otros) y llevando un registro tanto fotográfico ${ }^{1}$ como fílmico de diferentes espacios y momentos de esta celebración, y además indagando en periódicos digitales locales y redes sociales.

Desde una perspectiva interdisciplinaria, entonces, apuntamos a comprender mejor una forma de negociación que tiene lugar en esta celebración mediante la articulación de diferentes símbolos y prácticas, donde las expresiones que atraviesan este contexto, ya sea mediadas por la palabra o propias del discurso kinésico, se abren claramente a un proceso de transculturación. Nuestra hipótesis es que la hibridez cultural que aquí se torna manifiesta, se sirve fundamentalmente de la diferencia y la alteridad, puesto que no responde a mecanismos de homogeneización ni de reducción o adaptación de una cultura. Creemos que tampoco se trata de una disputa que deba ser pensada en términos interculturales sino más bien transculturales. ${ }^{2}$ Es decir, nos enfrentamos a un fenómeno a partir del cual la construcción de la identidad no es el resultado de una síntesis dialéctica, sino que más bien germina en un entramando de interacciones que es global y nómade, pues se encuentra en constante flujo y cambio.

Cuando hablamos de hibridez específicamente nos referimos al modo en que Alfonso de Toro alude a una estrategia que "relaciona y conecta elementos étnicos, sociales y culturales de la Otredad en un contexto político-cultural donde el poder y las instituciones juegan un papel fundamental" (2005, p. 19). Lo híbrido no resulta ni expresa lo indeterminado, porque remite a formas desarrolladas históricamente (García Canclini, 1989). Además, en tanto término amplio y general, que denota macroprocesos culturales que siempre implican un desplazamiento o migración como la desterritorialización y la reterritorialización, engloba otros conceptos más específicos como los de transmedialidad y transculturalidad (Toro, 2014). Aquí nos interesa fundamentalmente este último, que, como proceso de negociación de carácter no binario, no remite a la desculturización ni a la pérdida o desarraigo ni a la homogeneización, ni tampoco plantea órdenes jerárquicos, sino

1 Parte del material fotográfico fue incluido en la muestra Postales de la fe migrante (Fotógrafos: Mauricio Martínez, Camila Bonaudo e Inti Castellanos. Director del proyecto: Fabián Flores. Texto curatorial: Carolina Vogel y Carlos Luciano Dawidiuk), que se exhibió durante el mes de junio de 2018 en la Universidad Nacional de Luján. Se puede acceder a las fotografías desde el siguiente enlace: http://www.giepec.com/muestra.html.

2 Como se verá más adelante, resulta más adecuado hablar de transculturalidad, en el sentido propuesto por Toro (2005), para dar cuenta de la interacción de elementos culturales relativos a diferentes esferas espaciales (local, regional, nacional y global). De este modo, solo guarda similitudes con el concepto clásico enunciado por Fernando Ortiz $(1983$, pp. 83, 88, 90) en la medida en que alude a un "entrecruzamiento" de culturas. Pero se diferencia esencialmente en que no está ligado a nociones de "pérdida" y "desarraigo", ni tampoco es un "resultado definitivo sintético homogeneizante de la cultura, sino un proceso continuo e híbrido" (Toro, 2005, p. 22). No implica una "síntesis", "sino una tensión (no dialéctica) entre diversos elementos dentro de una estrategia de hibridación” (Toro, 2005, p. 23). 
que se manifiesta en tensiones no dialécticas entre diversos elementos culturales que se van entrecruzando en un proceso continuo e híbrido (Toro, 2005).

Asimismo, es importante focalizar en el reconocimiento de la diferencia, en los mecanismos por los cuales se constituye y exterioriza en el contexto analizado, ya que posibilita la negociación de las significaciones y el desarrollo de los actos performativos en un tercer espacio, tal como lo plantea Homi Bhabha (2013), como aquel lugar donde afloran las identidades híbridas.

Vale recordar que, como señala Renato Ortiz (2005), el espacio y el tiempo no son categorías abstractas, sino que devienen de las concepciones sociales del pensamiento que se materializan, por ejemplo, en el modo en que se produce el ordenamiento físico de la ciudad. Pero la estrecha relación mantenida con esa materialidad no implica que debamos identificarla con esa dimensión. Es por ello que en el contexto de mundialización de la cultura en el que vivimos, somos testigos de la producción de imaginarios y memorias populares que se articulan o mezclan en espacios-tiempos transversales respecto a las dimensiones local, nacional y global, facilitados en gran medida por los medios electrónicos o los mass media (Ortiz, 2005).

De este modo, en la creación de un tercer espacio, tal como sucede en la peregrinación de la que aquí nos ocupamos, la desterritorialización de prácticas, creencias y símbolos surgidos, arraigados, desarrollados y/o identificados con lugares o regiones circunscritos al territorio nacional boliviano o, incluso, a una noción espacial más amplia de mundo andino, implican al mismo tiempo su reterritorialización. En este sentido, la desterritorialización libera al espacio del "medio físico que lo aprisionaba", mientras que la reterritorialización "lo actualiza como dimensión social" y lo reubica, lo "localiza" (Ortiz, 2005 , p. 63). Se trata aquí de otro aspecto de lo que Ortiz propone concebir como la "transversalidad" de las culturas (Ortiz, 2005, p. 61).

Por otra parte, en sintonía con las propuestas de Ortiz, Alicia Lindón (2017) hace hincapié en que es justamente el sujeto-habitante quien imprime su forma a las ciudades, siempre en y mediante el movimiento. Al mismo tiempo, el sujeto elabora internamente el mundo externo en el marco de esta vinculación dinámica con el espacio, dado que "la comprensión misma que hace el sujeto habitante de sus lugares en la ciudad constituye una forma de movimiento, porque lleva consigo procesos de cognición espacial de un entorno que es múltiple" (Lindón, 2017, p. 110). Por ello, también, dicho entorno espacial se caracteriza por poseer múltiples lógicas propias de movimiento que inducen de manera constante a la producción de nuevas comprensiones, que devienen de la necesidad a la que se enfrenta el urbanita de estar elaborando internamente el cambio permanente del mundo externo. Y, como afirma la autora, "en estos procesos de comprensión del entorno, los sujetos van dotando de significados, valores y memoria cada lugar donde se hayan inscrito acontecimientos de su propia trayectoria biográfica" (Lindón, 2017, p. 110). 
Es importante señalar que dichos saberes internalizados no solo existen en las personas como una capacidad de agencia individual, sino que son disposiciones encarnadas en ellas como "co-agencia respecto a encadenamientos de acciones" (Lindón, 2017, p. 111). En este sentido, "todos los movimientos corporales de un habitante están relacionados con saberes que otros también poseen y que permiten que unos y otros participen en secuencias de acciones, que en última instancia son formas de colaboración encarnadas en nosotros" (Lindón, 2017, p. 111). Del mismo modo, la manipulación del tiempo vivido también constituye una forma de movimiento mediante la que se dota de densidad al presente en el desarrollo de sus acciones, articulando el acervo experiencial del pasado con un horizonte futuro en cada intersección que representa un ahora.

Así, pensar la ciudad como espacio-movimiento nos permite, frente a nuestro caso, dimensionar y comprender mejor la emergencia del tercer espacio como la materialización en las corporalidades y en las prácticas de relaciones intersubjetivas e interdiscursivas, de articulaciones de temporalidades y espacialidades, que posibilitan modos concretos de agencia y negociación.

Finalmente, resulta necesario clarificar la noción de identidad a la que apelamos aquí, que guarda relación directa con el concepto de hibridez desarrollado más arriba, y que se halla presente en los planteos de Bhabha, Ortiz y Lindón. Al contrario de las posiciones esencialistas, entendemos que la identidad no es fija, sino que "es una construcción simbólica que se hace en relación con un referente" (Ortiz, 2005, p. 77), es decir, frente a lo que se percibe como otra/s identidad/es. Dicha construcción se sustenta siempre sobre procesos creativos y dinámicos de memoria, tal como se puede inferir a partir del concepto de memoria colectiva elaborado por Maurice Halbwachs (2004), que se asienta en los marcos sociales de la memoria, en tanto instrumentos que posibilitan la fijación de recuerdos, dotándolos de sentido al articularlos con otros elementos más fijos o estables; o de las nociones propuestas por Jan Assman (2008) de memoria comunicativa, vinculadas a las experiencias compartidas y la interacción frecuente dada en contextos espaciales de cercanía; y de memoria cultural, que implica una selección, tipificación y ritualización de sus componentes y se apoya en diferentes medios e instituciones para garantizar su transmisión. En este sentido, nuestra concepción de la identidad se corresponde con la noción de identidad narrativa propuesta por Paul Ricoeur (1996), en la medida en que los actos de memoria instituyen relatos tanto en el plano individual como en el intersubjetivo que permiten establecer tramas causales entre el pasado, el presente y el futuro. Esto posibilita la articulación de un sentido y una coherencia que dan lugar a la constitución y la continuidad identitaria, ya sea como sujetos o como pueblos a través del tiempo, posibilitando la acción sobre el presente más allá de la medida en que puedan ajustarse los elementos narrativos verídicos o ficcionales a lo efectivamente acontecido. 


\section{Una peregrinación singular}

La ciudad de Luján recibe anualmente la visita de una innumerable cantidad de fieles que tienen como centro de atracción principal a la Basílica y, por supuesto, a la Virgen de Luján, patrona de Argentina, Uruguay y Paraguay. El espacio público que circunda al templo no solo parece cobrar una vida particular con la afluencia de turistas religiosos cada fin de semana, sino mucho más aún con las multitudes que participan en las diversas peregrinaciones que tienen lugar en momentos determinados del año. Todas estas manifestaciones se despliegan en un espacio que se configura como hierópolis ${ }^{3}$ o ciudad santuario.

Sin embargo, la manera en que el espacio se dispone funcionalmente en cada una de las distintas peregrinaciones, genera una trama entre lo sagrado y lo profano en la que los diferentes ritos performativos legitiman su sacralidad de modos particulares. En este sentido, la celebración de la Virgen de Copacabana que aquí nos ocupa, es la que tal vez presenta una mayor cantidad de rasgos distintivos que dan lugar al despliegue de un paisaje religioso que es percibido por muchos espectadores, sobre todo locales, como un fenómeno atractivo y, en cierto modo, exótico.

Así, mientras varias de las peregrinaciones destacan como un componente esencial el esfuerzo que implica llegar caminando al templo desde largas distancias (o a caballo, como en el caso de la Peregrinación Gaucha), gran parte de los participantes de esta ceremonia no atribuyen una gran relevancia al desplazamiento. Tampoco se caracteriza por tener como principal motivación el cumplimiento de promesas o la realización de pedidos, hecho estrechamente vinculado a la acción de un peregrinar más clásico, ni suele relacionarse con desafíos personales. El móvil principal de los participantes, según se desprende de nuestras observaciones y entrevistas, se orienta más bien al agradecimiento y la veneración a la advocación de María, que representa la unidad del pueblo boliviano, la Mamita de Copacabana y patrona de Bolivia. Tal vez esto, incluso, responde a una lógica de la reciprocidad extendida en el mundo andino (Casanello, 2016).

La primera parte de la celebración, también nos permite observar una serie de rasgos distintivos. Esta comienza con una tradicional misa en la plaza, seguida de una procesión alrededor de la misma con los distintos santos y advocaciones marianas (entre las que tal vez se destacan respectivamente, en los últimos años, las vírgenes de Urkupiña, de

3 Esto se evidencia en ciertas lógicas funcionales, como el de poseer un orden espiritual dominante en donde lo sagrado impone su hegemonía sobre otras esferas; presentar diferencias entre una temporalidad vinculada a lo sagrado y un tiempo común; el hecho de que el alcance de la hierofanía no responde a costos de transferencia relacionados con la distancia; presentar itinerarios devotos en cierto modo preestablecidos mediante los cuales los peregrinos vivencian la experiencia de lo sagrado; y su organización signada material y simbólicamente por un lugar "central, un "punto fijo", sagrado (Rosendahl, 2009, pp. 47-48). Flores (2012) ha analizado con más detalle la constitución de la ciudad de Luján como una hierópolis. 
Chaguaya y de Cotoca) en andas, encabezada por las dos principales, la Virgen de Copacabana y la Virgen de Luján.

En este primer segmento, que se corresponde con la centralidad del ritual ${ }^{4}$ litúrgico (o religioso, según las palabras de varios entrevistados), aunque marcado por un contenido importante de elementos cívicos y políticos particulares, nos permite asimismo identificar una serie de atributos esenciales de esta peregrinación: el izamiento de las banderas boliviana, argentina y papal en los mástiles de la plaza a manos de las autoridades locales y las autoridades consulares bolivianas, la entonación de los himnos de ambas naciones, la presentación de los funcionarios seguida de sus discursos formales, la ubicación de una multitud de familias junto a sus santos o advocaciones marianas en la plaza, organizada en secciones dividas por los colores de la bandera boliviana, entre otras.

Un rasgo llamativo que observamos en esta primera parte tiene que ver con la procesión, en la que se llevan los santos y advocaciones marianas de cada familia (ver imágenes 1-4). Esto se corresponde con una costumbre prehispánica, según la cual se sacaba a los muertos de sus tumbas y se los paseaba en la época de lluvias para recibir su bendición sobre las cosechas. Con la evangelización, esta práctica pasó a considerarse un acto profano y los muertos fueron reemplazados por santos católicos (Lara Barrientos y Córdova, 2011). Asimismo, es interesante notar que los santos coexisten en la plaza sin ningún tipo de conflicto, ${ }^{5}$ y si bien el homenaje principal es rendido a la Virgen de Copacabana, cada uno de ellos recibe su correspondiente homenaje, no solo por las familias, sino por las compañías de bailarines quienes en diferentes puntos del recorrido se arrodillan brindando su ofrenda, que es su mismo cuerpo devenido en danza hasta el cansancio (ver imágenes 5-8).

4 Entendemos el ritual como un evento extraordinario que perturba lo cotidiano y que implica una preparación especial de tiempo y espacio (Smietniasky, 2012), que además cuenta no solo con una determinada organización y acuerdo social, sino que conlleva una preparación psicológica, física y espiritual de quienes se disponen a participar de él (Douglas, 2007).

5 Esto no implica que no existan tensiones, sobre todo respecto al momento de llegada a la plaza, que determina los puntos jerárquicos en la disposición de un orden más bien territorial de las advocaciones frente al palco central. Por ejemplo, Angélica, una animadora de la Pastoral Boliviana que participa desde hace más de diez años en esta peregrinación, nos menciona que "hay muchas devociones, que se van dispersando (...) una devoción se enoja con la custodia y traen otra imagen y hacen más devociones, y eso es lo que no tendríamos que hacer, sino unificar porque María es una sola” (Entrevista, 6/8/2017). 

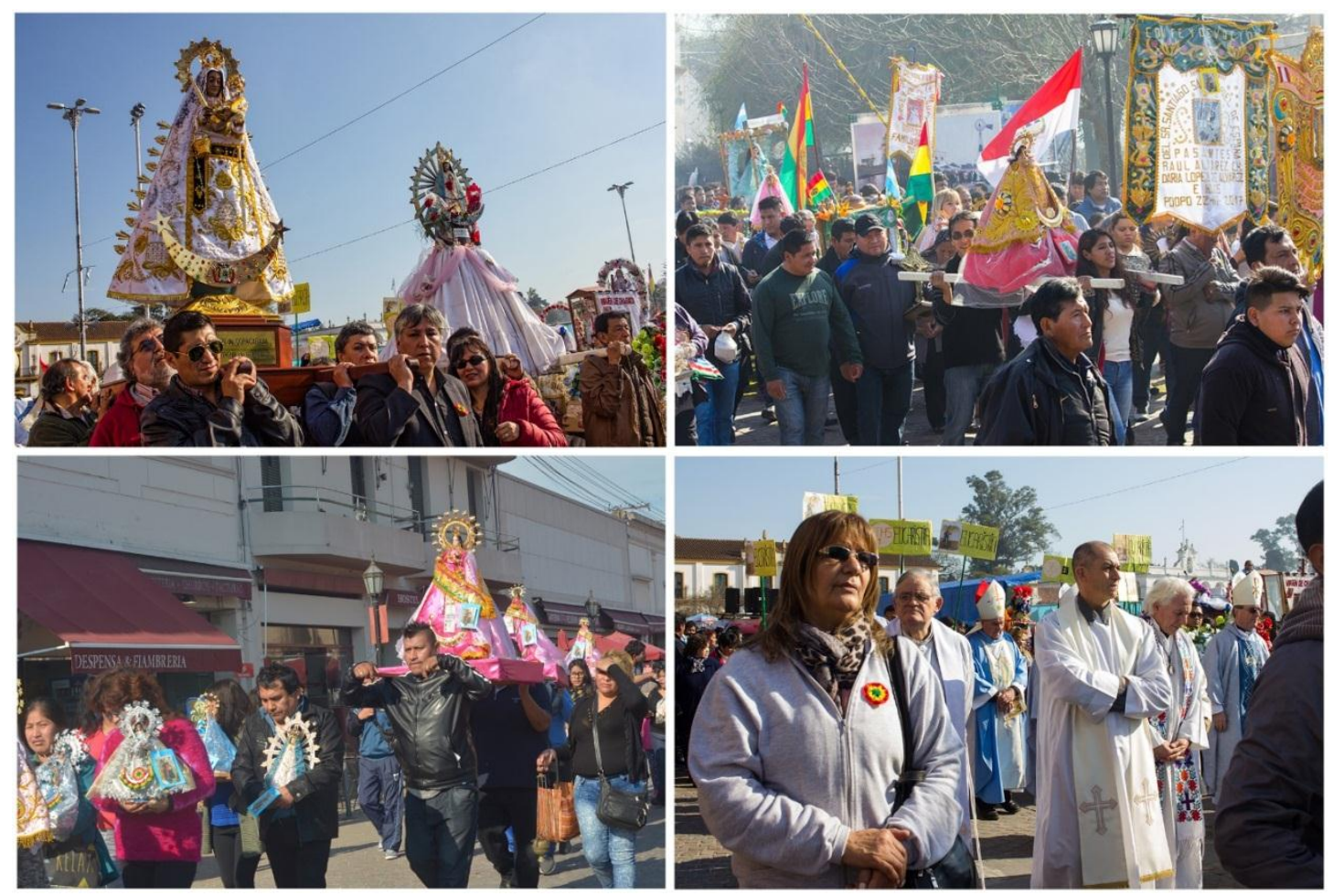

\section{Imágenes 1-4 Procesión}

En la imagen 1 (arriba a la izquierda) puede observarse a la Virgen de Copacabana (izquierda) y a la de Luján (derecha). Las imágenes 2 y 3 (arriba a la derecha y abajo a la izquierda), muestran a los fieles llevando en andas las advocaciones. En la imagen 4 puede verse a los sacerdotes que auspiciaron la misa. En este conjunto de imágenes se percibe también la presencia de símbolos identitarios como las banderas boliviana, argentina y de Tarija (blanca y roja) o la escarapela boliviana.

Fotografías: Mauricio Martínez, Camila Bonaudo e Inti Castellanos

Este acto simbólico de arrodillarse ante el santo o la advocación mariana de alguna familia, como componente específico del ritual, carga de sentido la acción y nos hace pensar en esa hermandad a la que se apela constantemente desde lo discursivo, como mecanismo de identificación con la alteridad para dejar de concebirse como "otros" y pasar a reforzar el sentido del "nosotros". El santo puede pertenecer a una familia diferente, con una adscripción territorial particular y una devoción que también remite a una historia especial, que configuran rasgos identitarios distintivos. Pero en este contexto de prácticas religiosas desterritorializadas y reterritorializadas que exigen la construcción de la identidad boliviana en Argentina, en el acto de arrodillarse se reconoce a todas estas figuras, y a los símbolos que encarnan, como propios. 

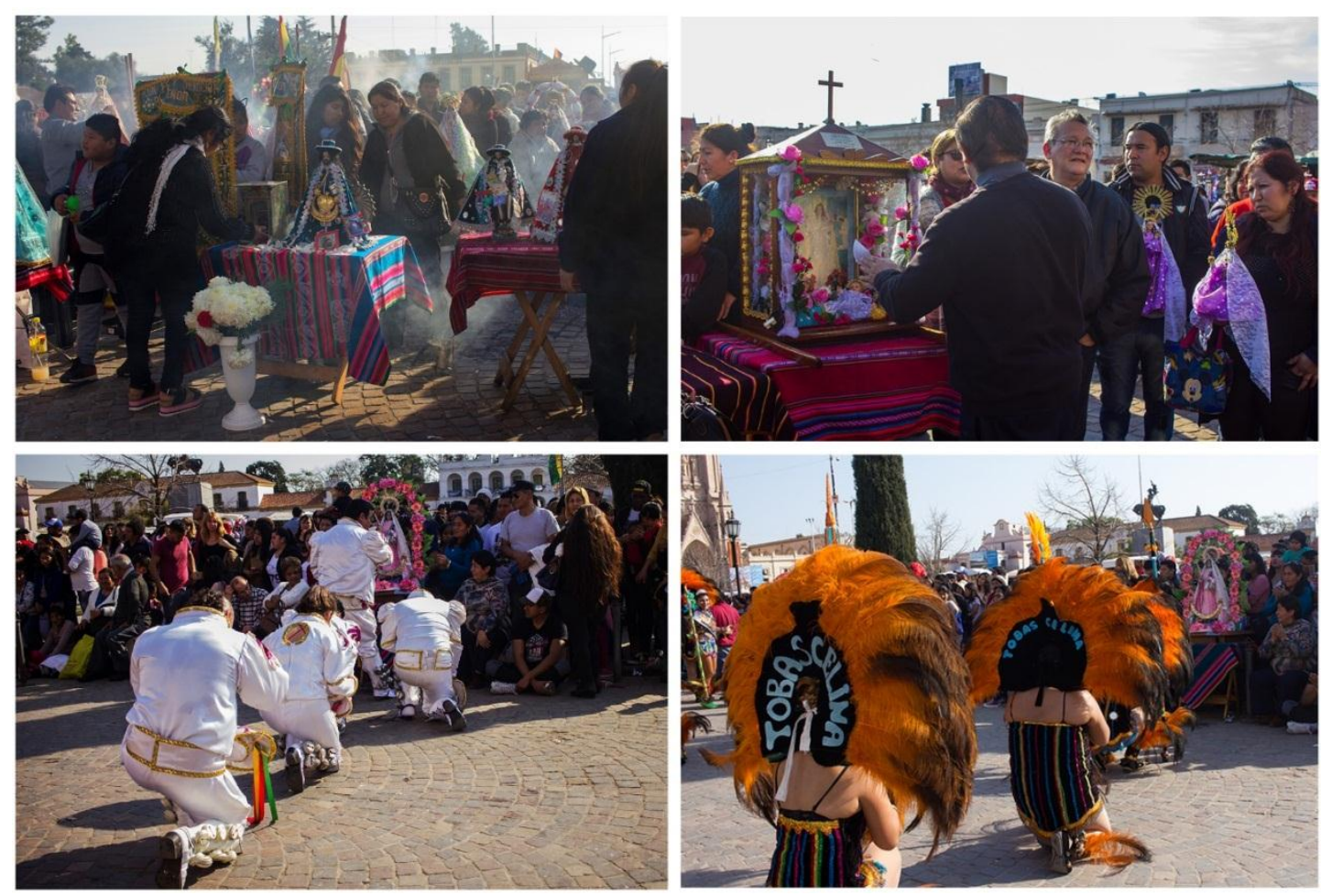

Imágenes 5-8 Santos y advocaciones marianas

En las imágenes 5 y 6 (arriba) se puede observar a las familias con sus figuras religiosas. Se ubican en la Plaza Belgrano, de frente a la Basílica y a los escenarios, dentro del circuito de la procesión y de las danzas delimitado por vallas. En las imágenes 7 y 8 , se ve a los bailarines que hacen un alto para arrodillarse frente a alguna advocación.

\section{Fotografías: Mauricio Martínez}

Por cierto, la particularidad más evidente de esta celebración tiene que ver claramente con las manifestaciones dancísticas y musicales que la identifican, y el impacto visual del despliegue de los coloridos trajes de sus participantes, que se desarrollan en lo que podríamos considerar como una segunda parte. Luego de la misa y la procesión, se establece un circuito delimitado con vallas por donde los bailarines marchan danzando, detrás de las bandas musicales, que los separan de una multitud de espectadores. Los que abren el ritual de las danzas son los pasantes, que son quienes aportan el dinero para la celebración y también toman decisiones muy importantes, como la elección de las compañías que realizarán la apertura de las danzas, y pueden influir además en la participación de agrupaciones, aunque de ello se ocupan instituciones específicas como la Unión de Fraternidades Folclóricas y Organizaciones Bolivianas (UFFOBOL) y la Asociación de Conjuntos Folklóricos De Residentes Bolivianos en Argentina (ACFORBA), "Rojo, amarillo y verde" y "Morenadas". Con respecto a estas entidades, podemos señalar que también se producen diversos conflictos que tienen que ver sobre todo con la participación de las compañías de danza. Resulta notorio que la morenada, el 
caporal y el tinku ${ }^{6}$ se constituyen como una especie de bailes mainstream, cuya participación es mucho mayor si se la compara con otros grupos minoritarios como el de la Saya Yunguera o los de Salay, ${ }^{7}$ o los bailarines tupiceños que bailan tonadas al ritmo de la Anata. Esto resulta en una lucha muy intensa por formar parte de las celebraciones (ver imágenes 9-12).
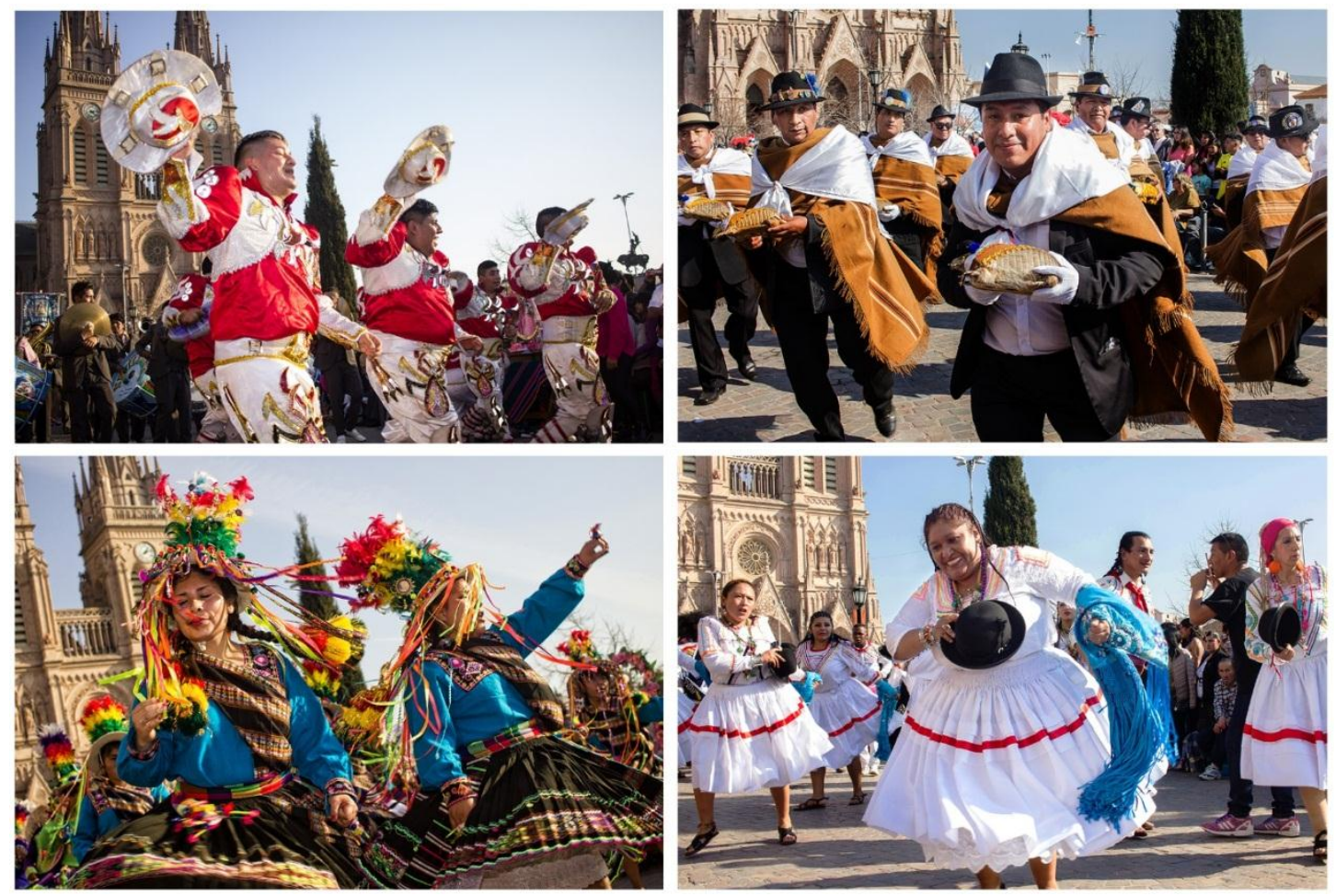

\section{Imágenes 9-12 Las Danzas}

Imagen 9 (arriba a la izquierda), la danza Caporal, derivada de la Saya Yungueña, nació en 1971 en el contexto de la festividad del Gran Poder. Es una expresión satírica del trabajo de los esclavos en las minas y en los viñedos, y resalta la fuerza y la sensualidad. Imagen 10 (arriba a la derecha) la Morenada es una danza del altiplano inspirada en la esclavitud cuyo origen se remonta a la época colonial. Imagen 11 (abajo a la izquierda), el Tinku (lit. "encuentro"), es una danza moderna que evoca un combate ritual del período preincaico. Simboliza la lucha entre diferentes comunidades, estaba dedicada a la Pachamama a quien se imploraba por la buena cosecha, e implicaba el derramamiento de sangre y hasta la pérdida de la vida. Imagen 12, la Saya Yungueña es una manifestación cultural de las comunidades afrobolivianas, originaria de la región de los yungas del Departamento de La Paz.

\section{Fotografías: Mauricio Martínez}

6 La morenada es un baile altiplánico de origen colonial, inspirado en el trabajo de los esclavos traídos por los españoles para trabajar en las minas de plata del Alto Perú. La danza de los caporales, es relativamente nueva, resalta la fuerza y la sensualidad, y proviene de la Saya de los negros de la yunga boliviana y que nació en 1971 en el contexto de la festividad del Gran Poder. El tinku (ay. "encuentro") simboliza la lucha entre diferentes comunidades, dedicada a la Pachamama a quien se implora por la buena cosecha. Históricamente este ritual ha conllevado el derramamiento de sangre para fecundar la tierra, mediante una pelea cuerpo a cuerpo entre los participantes de comunidades enfrentadas.

7 La saya, que comprende tanto la danza como la música y la poesía, es una expresión propia de las comunidades afrobolivianas. El salay es un baile moderno, nacido de la combinación de danzas de los valles de Potosí, Chuquisaca y Cochabamba. 
La figura del pasante en sí juega un importante papel simbólico, dado que aún en las celebraciones de Argentina se sigue manteniendo esta figura de tradición andina, cuyos paradigmas culturales de lazos sociales tienen que ver con la dualidad reciprocidadredistribución y el con prestigio (ver imágenes 13-16). Este último aspecto es consecuencia directa de la generosidad y la abundancia: quienes no dan muestras de generosidad nunca podrán gozarlo. Por tanto, es un honor para las familias aportar recursos económicos para la celebración y es prestigioso para la comunidad ocupar el lugar de los pasantes, pues serán recompensados con la reciprocidad que recibirán de la Virgen por tan honrado acto de dar (Revollo Fernández, 2015).
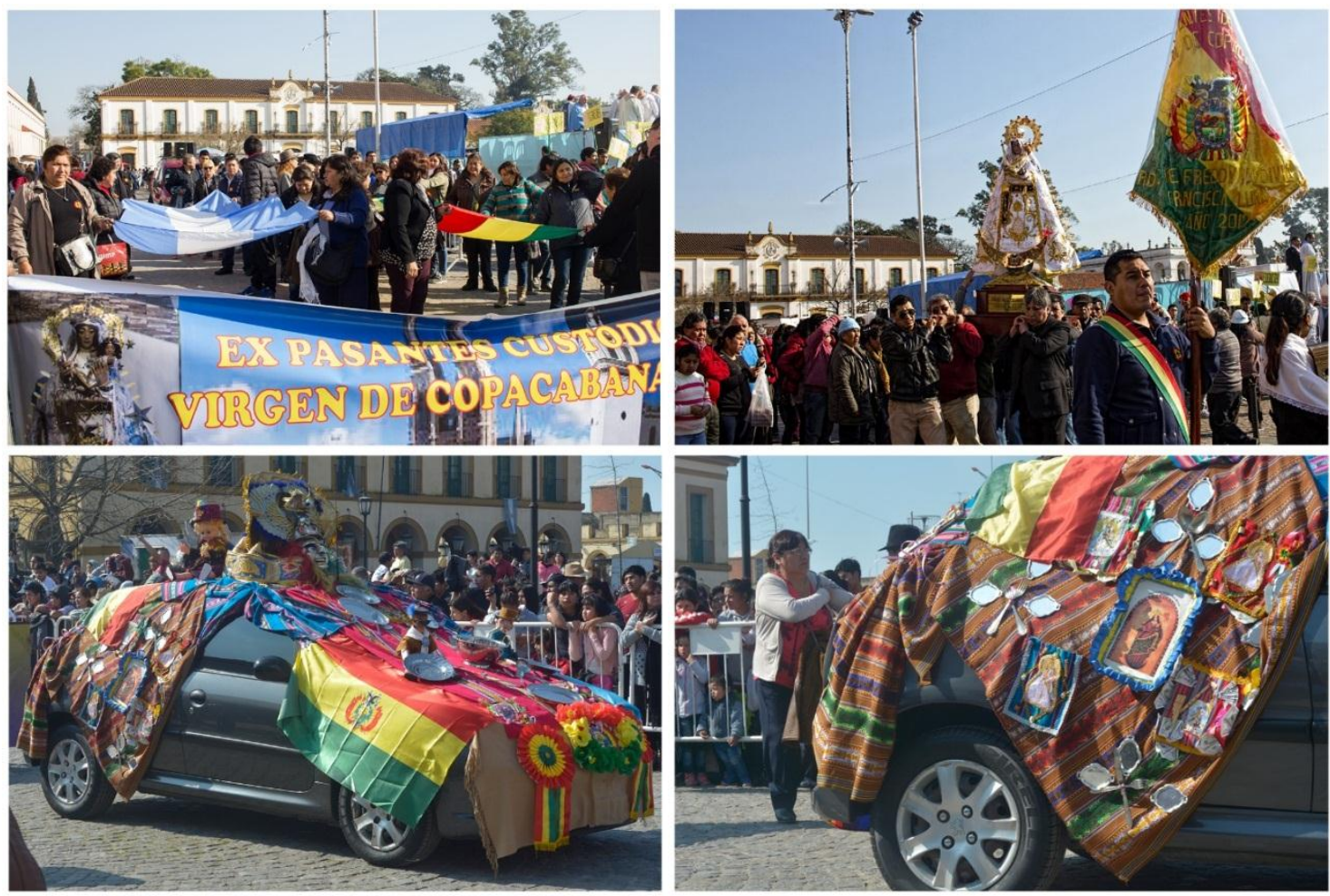

\section{Imágenes 13-16 Los pasantes}

Imágenes 13 y 14 (arriba), los pasantes son devotos que participan en la celebración en calidad de patrocinadores y organizadores. Se renuevan cada año y establecen entre ellos (salientes y entrantes) lazos de solidaridad y de compadrazgo. Imágenes 15 y 16 (abajo), los "pasantes de carga" (o "promesantes de carga"), adornan sus autos con bienes de consumo y otros elementos tradicionales, y ponen a prueba su fe mediante promesas a la Virgen.

Fotografías: Mauricio Martínez y Camila Bonaudo

Un matiz muy relevante y específico de este segundo momento, se observa en la conformación de un círculo sostenido por el movimiento ininterrumpido e incansable de las compañías de danza, acompañado del sonido continuo de las bandas que tocan hasta el anochecer. La performance dancística y musical involucra tanto al cuerpo individual como al cuerpo colectivo de los bailarines que van actuando a lo largo del recorrido (ver imagen 17). 


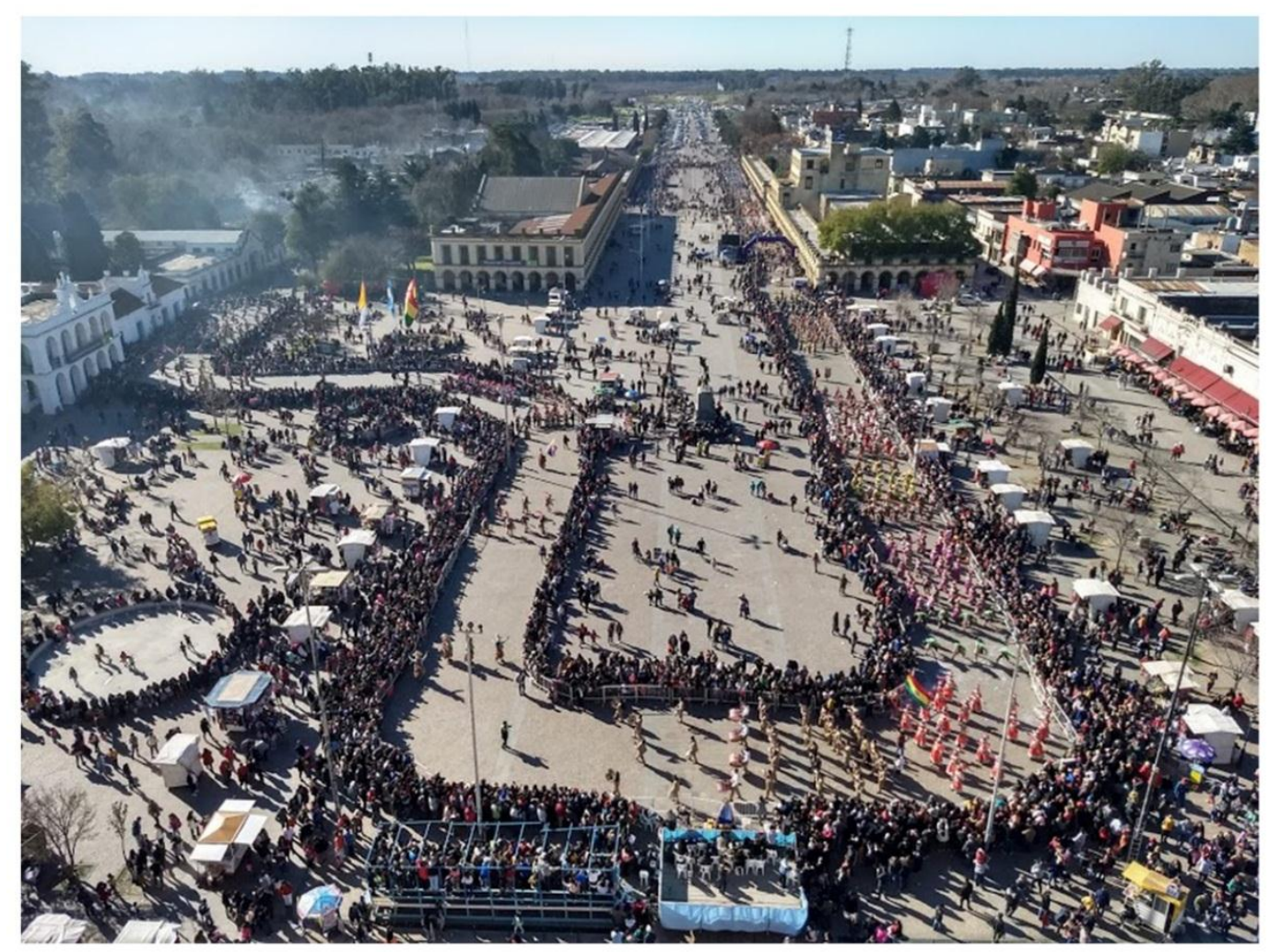

Imagen 17 - La plaza

Vista de la Plaza Belgrano desde arriba de la Basílica de Luján.

Fotografía: Pablo Lisetto

Resulta difícil traducir en palabras el modo en que los sentidos se ven afectados por el efecto que genera dicha circularidad espacio-temporal, materializada y sostenida por la música y la danza. Vale decir también que este componente estético, a diferencia de lo que ocurre con otras manifestaciones religiosas, no solo convoca a un número considerable de fieles que expresan su devoción religiosa, sino que también concurren personas con el objetivo de disfrutar del espectáculo. Si bien la mayoría de los concurrentes pertenecen a la colectividad boliviana, y en muchos casos asisten a la celebración para acompañar y apoyar a familiares y amigos y para verlos danzar, con el correr de los años se ha conformado un público externo a dicho círculo, cuyo acercamiento tiene como único móvil el goce estético, incitado tal vez por el carácter percibido como exótico de esta expresión.

Otro rasgo distintivo, y si se quiere sumamente contrastante respecto a las diferentes peregrinaciones que afluyen a Luján, es el montaje de ferias de comidas y productos típicos bolivianos, a unas pocas cuadras de la celebración, y los escenarios montados en los recreos cercanos a la plaza, en los que se suceden innumerables grupos de música popular (mayormente de cumbia). Muchos de los espectadores y de los participantes de la procesión inicial, como así también músicos y bailarines, acuden allí a comer algo y a bailar antes y/o después de finalizar sus respectivas actividades. 
En algunos puestos de la feria se venden miniaturas de casas y autos, de vegetales y de botellas de alcohol. Estas figuras, que fácilmente pueden ser percibidas como elementos kitsch por parte de un transeúnte desprevenido, están presentes en las culturas andinas como alasitas. Se trata de imitaciones de las antiguas representaciones elaboradas con barro o pan, que eran enterradas como ofrenda para recibir algún bien. Hoy en día asumen este carácter de mercancías, pero continúan la forma de "espacios simbólicos de deseos de reciprocidad entre los oferentes y los creyentes, ahora convertidos en compradores y vendedores" (Lara Barrientos y Córdova 2011, p. 46). En tanto universo de los deseos y de los sentidos,

la feria de alasitas es el mercado de las miniaturas, pero más que eso, es el mercado de los sentidos, que expresan deseos, deseos individuales que por ser muchos y similares, se hacen colectivos. Este colectivo es el universo que abordamos, porque la Feria de Alasitas es el universo de los deseos, por tanto, el universo de los sentidos. (Lara Barrientos y Córdova, 2011, p. 46)

Una última característica importante a destacar es que esta peregrinación se enmarca en una serie de celebraciones que se desarrollan durante todo el año, entre las que se encuentran las dedicadas a otros santos de origen boliviano, como el Tata Bombori, la Virgen de Urkupiña, la Virgen del Socavón, la Virgen del Rosario o la Virgen de Guadalupe, entre otros, que se realizan en diferentes puntos de la provincia de Buenos Aires, asemejándose a los sucesivos convites del Carnaval de Oruro y a otras fiestas. Estas "entradas"8 de las fraternidades se despliegan en el espacio público y cada encuentro es una verdadera celebración multitudinaria.

Todo este conjunto de símbolos y acciones simbólicas, no solo resultan ser ambiguas y polisémicas, sino también contradictorias o paradojales. La creación de estas paradojas responde al trabajo simbólico mediante el cual los sujetos cubren sus "construcciones visibles e invisibles del mundo con una red de significados" (Figueroa-Dreher, Dreher y Soeffner, 2011, p. 21), que son consolidadas precisamente por los símbolos. Ello resulta factible "porque ellos poseen la propiedad de enfatizar paradojas y ambivalencias, pero al mismo tiempo de mantenerlas y resistirlas y de esa forma transformar las disonancias de lo opuesto en consonancias estéticas" (Figueroa-Dreher, Dreher y Soeffner, 2011, p. 21).

Resulta notoria, entonces, la importancia de la existencia de estos símbolos colectivos en tanto soportes de las emociones experimentadas con otros. De este modo, los símbolos colectivos "son los productos e instrumentos, expuestos a permanente confirmación, del trabajo humano sobre y con las condiciones de la convivencia en grupos, comunidad y sociedad", y en gran medida "constituyen el sentimiento de comunidad, así como también

8 Se denomina "entradas" a las diferentes festividades masivas, normalmente de carácter folklórico, que se suceden a lo largo del año. 
contribuyen a asegurar su conciencia (colectiva) y su continuidad" (Figueroa-Dreher, Dreher y Soeffner, 2011, pp. 21-22).

Así, un símbolo colectivo puede "ser caracterizado como la reunión, concentración y organización de ánimos, sentimientos y actitudes individuales en una reacción, experiencia y sentimiento común” (Figueroa-Dreher, Dreher y Soeffner, 2011, pp. 21-22). Es decir, que estos permiten vivir y asegurar experiencias colectivas, "para la comunidad que se unió en la reacción compartida suscitada por el símbolo, una 'unidad sentida' que se vive por cierto, de forma prerreflexiva- como unidad del sentimiento colectivo" (FigueroaDreher, Dreher y Soeffner, 2011, p. 22).

Estas vinculaciones emocionales de los sujetos a través de los símbolos son sumamente relevantes por el hecho de que ellos representan un plano de interdependencia distinto al de la persona individual que lo remite directamente a la consciencia ampliada del "yo (o mi) y nosotros", constituyéndose así como herramientas imprescindibles de cohesión para grandes y pequeños grupos humanos (Estados nacionales, asociaciones, compañía de danza, etc.) (Elias, 1970, p. 118). Pero, al mismo tiempo, ese carácter ambivalente o paradojal constitutivo del símbolo posibilita la hibridez en este escenario peregrino en el que se despliegan estrategias identitarias por parte del colectivo boliviano y tienen lugar procesos de desterritorialización y reterritorialización de la cultura.

\section{¿Una peregrinación extranjera?}

En este contexto de la hierópolis, pensada aquí también como espacio-movimiento, el recibimiento de un otro nos interpela, ya sea como sujetos habitantes, espectadores, o incluso en nuestro rol de investigadores, respecto a muchos aspectos que tienen que ver con la manera en que se recibe a ese extraño que modifica el paisaje con su presencia, pero que además nos enfrenta con el nosotros, al ubicarnos en esa posición de espectadores y no peregrinos.

En el caso específico de esta denominada "peregrinación boliviana", no solo nos encontramos con el extraño, sino fundamentalmente -dado el carácter que le imprime la propia nominación del evento como así también la impronta marcada por despliegue de las prácticas religiosas, culturales y estéticas señaladas anteriormente- con un sujeto que es reconocido como extranjero. Es importante notar que esta caracterización no surge simplemente como una etiqueta puesta desde fuera ni como un mecanismo identificatorio puramente interno, sino que más bien emerge de un entramado intersubjetivo más amplio. En este sentido resulta más comprensible el hecho de que un vasto número de estos peregrinos sean identificados como extranjeros, o bien asuman como propia dicha 
determinación, aún muchos años después de haberse naturalizado o incluso habiendo nacido en Argentina. ${ }^{9}$

De este modo, puede resultar fructífero pensar la noción de extranjero desde la óptica de Jacques Derrida, puestas en relación con las de hospitalidad y hostilidad (Derrida y Dufourmantelle, 2000). Así, el extranjero es en primer lugar un extraño frente a la lengua del derecho. En este sentido, todo migrante estaría siempre virtualmente expuesto a posibles actos de violencia material o simbólica. Pero, por otra parte, si bien para Derrida la hospitalidad constituiría una apertura incondicional frente a la otredad, una aceptación absoluta de su diferencia aún frente a su incomprensión, su interrogación en torno al lugar de la lengua hablada en relación a la condición de extrañeza da lugar a una ambigüedad interesante, a una paradoja. "Si ya hablase nuestra lengua, con todo lo que esto implica, si ya compartiésemos todo lo que se comparte con una lengua, ¿sería el extranjero todavía un extranjero y podríamos hablar respecto a él de asilo o de hospitalidad?" (Derrida y Dufourmantelle, 2000, p. 23).

Ahora bien, es significativo el hecho de que cuando Derrida hace referencia a la lengua, piensa en todas las implicancias que ello tiene. En este sentido, no solo interesa la dimensión del lenguaje hablado únicamente, sino la cultura, los modos de hacer y de ser, la cosmovisión de quien arriba al lugar que percibimos como nuestro. Como afirma el autor, "la lengua es un cuerpo, no se le puede pedir que renuncie a eso... Se trata de una tradición, de una memoria, de nombres propios" (Derrida, 2004, p. 66).

Al respecto, nos parece interesante visualizar varias aristas que devela esta reflexión para pensar la peregrinación boliviana en Luján y las posibilidades y límites de la agencia de sus participantes. En primer lugar, la lengua castellana, conjuntamente con las características espaciales y culturales de la hierópolis, brindan un marco para la hospitalidad frente a los peregrinos, que hacen posibles en términos generales la realización de esta celebración. Sin embargo, la identificación claramente como boliviana, y el despliegue simbólico que reafirma dicha filiación, ancla el sentido en la condición extranjera de esta manifestación, enfatizando en las relaciones de alteridad y de diferencia, invisibilizando o difuminando elementos compartidos o de cercanía.

Resulta llamativo, de este modo, que un gran número de los participantes son descendientes de bolivianos nacidos en Argentina y educados en escuelas públicas de nuestro país, lo que los ha hecho muy permeables a la construcción de la identidad cultural

9 Varios de nuestros entrevistados residen desde hace muchos años en Argentina y se han naturalizado. La mayoría de los jóvenes bailarines y músicos con los que hablamos son hijos de bolivianos que nacieron en Argentina, y suelen reconocerse como argentinos y bolivianos al mismo tiempo. Resulta ilustrativo el comentario de dos jóvenes oriundos de la localidad de Escobar (Buenos Aires), David y Emilce, que no conocen Bolivia, pero cuyos padres llegaron a la Argentina desde Potosí: "nuestra cultura es boliviana, pero como nacimos acá somos de Argentina; nos sentimos... un cincuenta y un cincuenta por ciento, argentinos y bolivianos". (5/8/2018) 
argentina propuesta por el propio dispositivo escolar. Aún más, muchos otros son ciudadanos naturalizados, y los modos de interacción cotidiana al habitar y trabajar en este suelo han favorecido el arraigo a esta tierra, como se evidencia en las referencias a los barrios o ciudades argentinas en sus banderas o bordados de los trajes, como así también a ciertas formas de expresión y modismos del lenguaje que afloran espontáneamente en las entrevistas.

Por otra parte, muchas prácticas y concepciones culturales del mundo andino son compartidas por poblaciones del Norte de nuestro país, espacio en el que además el desplazamiento a través de la frontera resulta en un flujo continuo y dinámico. Y, aun así, los elementos folklóricos o los mecanismos de fijación de identidades culturales nacionales se imponen con fuerza en la peregrinación, desatendiendo, desplazando u ocultando aquello que podría valorarse como un patrimonio común o compartido.

Resulta sustancial recuperar las reflexiones de Anne Dufourmantelle respecto al tratamiento de la noción de extranjero por parte de Derrida. Lo que emerge de dicha cavilación es, en definitiva, una geografía de la proximidad a partir de la cual las relaciones de alterización no tienen lugar en el marco de la oposición a lo externo y lejano, sino que se circunscriben a lo "cercano de lo cercano" (Derrida y Dufourmantelle, 2000, p. 10). Por tanto, la necesidad de definir una diferencia con el otro, que puede llegar a convertirse en la hostilidad misma, es la que designa todo lo excluyente a lo cercano, devastando desde adentro cualquier posibilidad de relación con la alteridad.

De este modo, podemos pensar que las identificaciones culturales y políticas que apuntan a marcar una diferencia entre bolivianos y argentinos, materializadas en las prácticas y símbolos que circulan en esta peregrinación, se encuadran en esta geografía de la proximidad. La distinción del colectivo boliviano en Argentina se nos presenta, en parte, como fruto de esa mirada otrificadora que no termina por reconocer nunca al naturalizado o al descendiente nativo como plenamente argentino, impregnándolo en mayor o menor medida de una hostilidad que lo ubica en un lugar de extranjero eterno. Pero podemos pensar que, al mismo tiempo, dicha diferenciación brota como una estrategia de hibridación y de reterritorialización de la cultura en respuesta a ese prejuicio o contrariedad. Entonces, si concebimos a las identidades en tanto construcciones simbólicas que se forjan en relación a un referente, en un marco de competencia y conflicto, tal como propone Ortiz (2005), podemos conjeturar, entonces, que la construcción de la bolivianidad en Argentina se da con tanta o más fuerza que en la propia Bolivia, al anteponer la dimensión de una identidad nacional boliviana frente otras regionales o locales, en este marco de tensión y conflicto dado por la interacción con otras identidades. $^{10}$

$10 \mathrm{Al}$ preguntar a nuestros entrevistados sobre cuál es la importancia de esta celebración, la mayoría señaló que esta era una oportunidad para reunirse con otros compatriotas, al mismo tiempo que para expresar su 


\section{Negociación, tercer espacio e hibridez}

Llegados a este punto, resulta claro que la peregrinación boliviana en Luján opera transformaciones sobre el paisaje urbano, fundamentalmente a partir de la acción de los cuerpos-peregrinos en movimiento. Pero la percepción de este despliegue ceremonial y de sus efectos espaciales como una especie de muestra cultural o identitaria esencialmente boliviana por parte de aquellos espectadores desprevenidos, atraídos por la espectacularidad o el exotismo que encuentran en este fenómeno, se funda en una mirada parcial y, en mayor o menor medida, prejuiciosa y/o estereotipada. Del mismo modo, la concepción del peregrino-migrante es, por lo menos, incompleta cuando se la contrasta con una indagación más profunda en torno al origen y las adscripciones identitarias de los participantes.

El espacio público parece convertirse en un "pedacito" de Bolivia: ${ }^{11}$ la procesión de un variopinto conjunto de santos y advocaciones marianas de distintas localidades de ese país, el montaje de las ferias donde circulan objetos extraños como las alasitas o comidas típicas, los cantos y las onomatopéyicas expresiones de alegría, el desfile de una multiplicidad de trajes y máscaras que abundan en colores y estilos, el desplazamiento incansable e imponente de las compañías de danza acompañadas de la música de las bandas de marcha que invade cada rincón de la plaza y se proyecta inclusive más allá del espacio al que circunscribe esta festividad, son elementos esenciales a partir de los cuales se llevan a cabo esas transformaciones.

Sin embargo, muchos otros generan diversos matices o contrastes: la misma Virgen de Luján, la bandera y el himno argentinos, las referencias a localidades mayormente de la provincia de Buenos Aires y a barrios de Capital Federal en trajes, banderas, instrumentos musicales, cantos y en los propios nombres de las compañías, los pesos argentinos ofrendados a los santos y las músicas populares argentinas ejecutadas por las bandas de vientos (ver imágenes 18-21). Al mismo tiempo, como ya hemos señalado, un gran número de los participantes son residentes de nuestro país, varios de ellos naturalizados desde hace bastante tiempo y otros nacidos en Argentina. Entre estos últimos, sobre todo jóvenes de entre 18 y 30 años, en cuya manera de hablar resultan notorios los localismos rioplatenses, muchos expresan la necesidad de recuperar o conectarse con sus raíces

devoción a la Virgen. Estefanía, una joven bailarina nacida en Argentina, pero de padres bolivianos, refiere a que "es una buena manera de juntarnos todos y mostrar nuestra cultura, acá en el país que tanto nos da" (5/8/2018). Janet, una abogada oriunda de La Paz que vive Argentina desde hace más de treinta años y participa en la peregrinación desde su llegada al país, señala que se trata de "hermanar los pueblos, es la integración, es el amor. Porque Dios es amor y para Dios no existen las fronteras de los países" $(6 / 8 / 2017)$.

11 Los entrevistados ponen especial énfasis en estas similitudes. Varios de ellos, nacidos en Bolivia, hacen referencia a su propia experiencia como bailarines y/o espectadores en su tierra natal. Sin embargo, entre aquellos que nacieron en Argentina y nunca visitaron el país vecino, encontramos las mismas afirmaciones ("esto es igual a Bolivia", "es lo mismo que en Bolivia" o "así son las fiestas allá en Bolivia"). 
bolivianas, pese a no conocer Bolivia o a haber viajado en escasas ocasiones a sitios puntuales vinculados a sus familias paterna o materna. También nos encontramos con músicos y bailarines argentinos que forman parte de alguna banda o compañía solo por placer, o bien, a modo de actividad laboral.
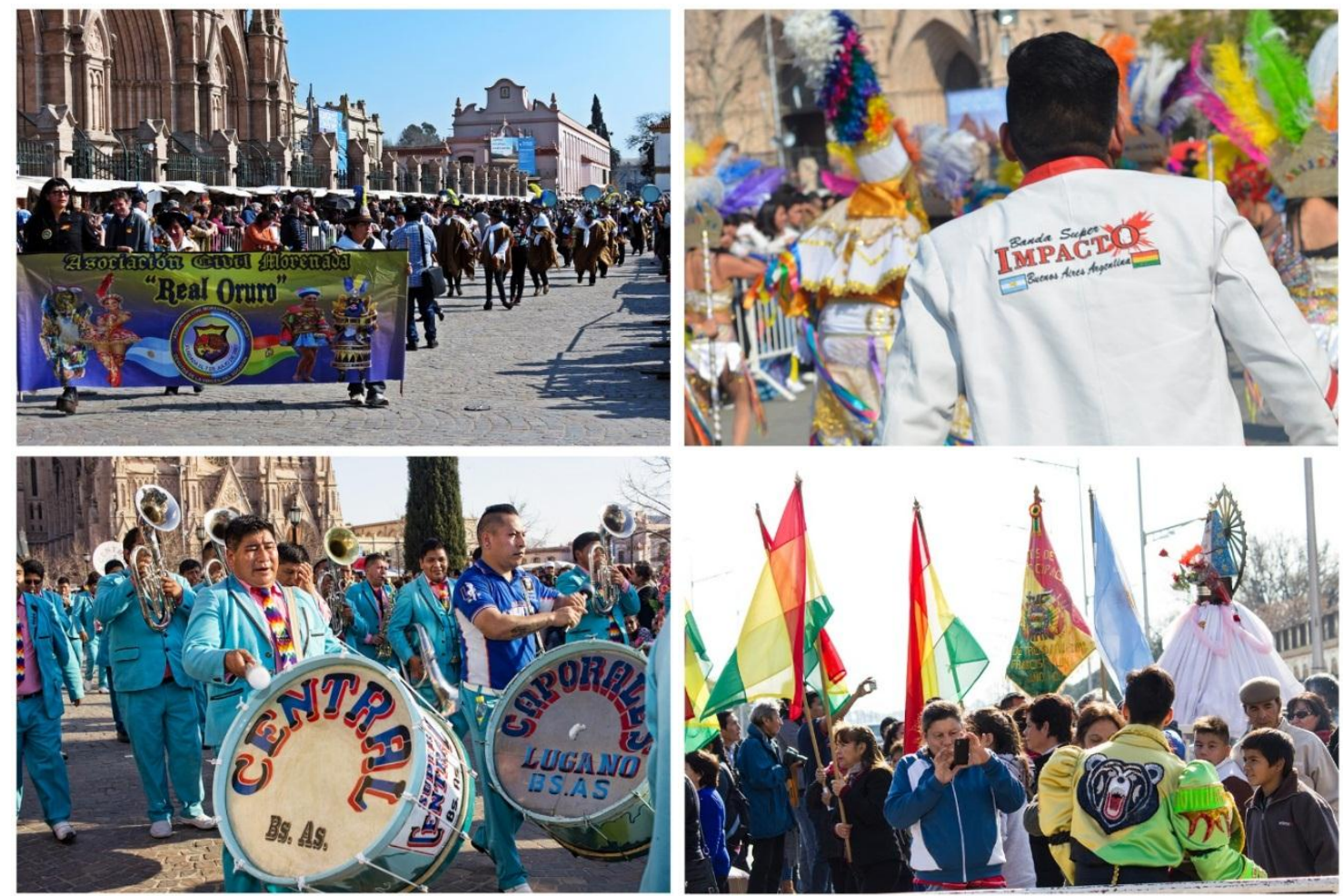

Imágenes 18-21 Referencias territoriales híbridas

Fotografías: Mauricio Martínez e Inti Castellanos

Es por ello que concebimos esta manifestación tan compleja como un proceso de negociación que tiene lugar justamente en un tercer espacio, atravesado por la yuxtaposición, mezcla y/o articulación de símbolos, prácticas y discursos que tienen como soporte principal los cuerpos y que se materializan en la creación del paisaje peregrino mediante el movimiento. Como señala Bhabha, es en "ese momento intersticial que se produce a través de la negociación de la contradicción y la ambivalencia" (2013, p. 31). El trabajo conjunto, la fricción de esas "liminalidades ( „no los límites!) de la hospitalidad y el lenguaje revelan el tercer espacio como un sitio asequible, si bien inestable, para la acción y la decisión" (Bhabha, 2013, p. 32, cursiva del autor). ${ }^{12}$ Así, con la irrupción de los cuerpos danzantes cobra vida un espacio del que manan muestras de sensualidad y virilidad, la euforia despertada por los bailes y las músicas populares, y narrativas que giran en torno a lo ancestral o a memorias con diferentes anclajes espaciales develadas a

12 El carácter liminal del tercer espacio que propone Bhabha, puede entenderse en un sentido performativo, tal como se desprende de la concepción de "liminalidad" de Turner (1988): se trata de un espacio transitorio (o un "espacio otro", en palabras de Foucault), que no es un "aquí" o un "allá", sino ambos. 
través de los trajes, máscaras o canciones. Allí se desdibujan los límites entre lo sagrado y lo profano, pero también en relación a lo nacional, a la condición de peregrinos, de migrantes, de extranjeros.

Al mismo tiempo, al pensar esta festividad en términos de hibridez, proponemos una mirada que busca captar los modos en que se entrelazan los elementos señalados como superación de una relación dialéctica. Es decir, estos sujetos-peregrinos, así como ese universo simbólico desplegado a través de sus prácticas y expresiones, no terminan por ser una síntesis de dos culturas (o más, si atendemos a localismos y regionalismos), sino más bien un híbrido en el que operan culturas imbricadas, como resultado de la larga historia de la afluencia de inmigrantes bolivianos hacia la Argentina y del trazado de densas redes migratorias (Casanello, 2016). Así, nos enfrentamos a un proceso de desterritorialización y reterritorialización, en el que fenómenos como esta peregrinación representan modos de su realización, en los cuales tanto los migrantes, argentinizados en mayor o menor grado, como aquellos sucesores cuyo sentido de pertenencia ancestral, territorial y/o identitaria es fundamentalmente imaginado, ${ }^{13}$ reactualizan la cultura localizándola.

Asimismo, debemos considerar que no nos encontramos frente a un colectivo homogéneo, sino que la bolivianidad expresada se nutre de un modo de ser y hacer de culturas heterogéneas que comparten también, en tanto expresiones híbridas, la identificación con el Estado Plurinacional de Bolivia. Resulta igualmente evidente que la Argentina está atravesada por una diversidad cultural muy amplia. Como señala Toro (2005), la inexistencia de una cultura pura puede servir para sostener una perspectiva de la hibridación, tal vez un tanto extremista, en la que las múltiples influencias culturales y la articulación con las tecnologías de la comunicación cada vez más ubicuas, hacen de todos los sujetos híbridos culturales.

Por otra parte, volviendo a la concepción de la ciudad movimiento de Lindón (2017), podemos percibir la creación de un paisaje híbrido a partir del modo en que los sujetosperegrinos operan con sus prácticas sobre el espacio (ver imágenes 22-27). Como señala Doreen Massey (1999), lo espacial es siempre construido "como esfera de yuxtaposición o coexistencia de distintas narrativas, como el producto de relaciones sociales dinámicas" y los "lugares son imaginados como articulaciones concretas de estas relaciones sociales" (Massey, 1999, p. 152). En definitiva, “el lugar es un punto de encuentro poroso, abierto, híbrido" (Massey, 1999, p. 152).

13 En un sentido amplio, puede comprenderse esto en relación con la propuesta de Benedict Anderson (2007), que concibe las naciones como "comunidades imaginadas", en las cuales la imaginación representa el medio esencial por el cual los sujetos perciben su pertenencia a dicha construcción social. Pero de manera más específica Arjun Appadurai (2001) señala que la imaginación se ha vuelto en las últimas décadas, fundamentalmente gracias a la expansión de los medios electrónicos como a su profundo impacto en la constitución de las identidades, en un hecho social y colectivo, que se materializa en las posibilidades de las "comunidades de sentimiento" de sentir, proyectar y hacer cosas juntos. 

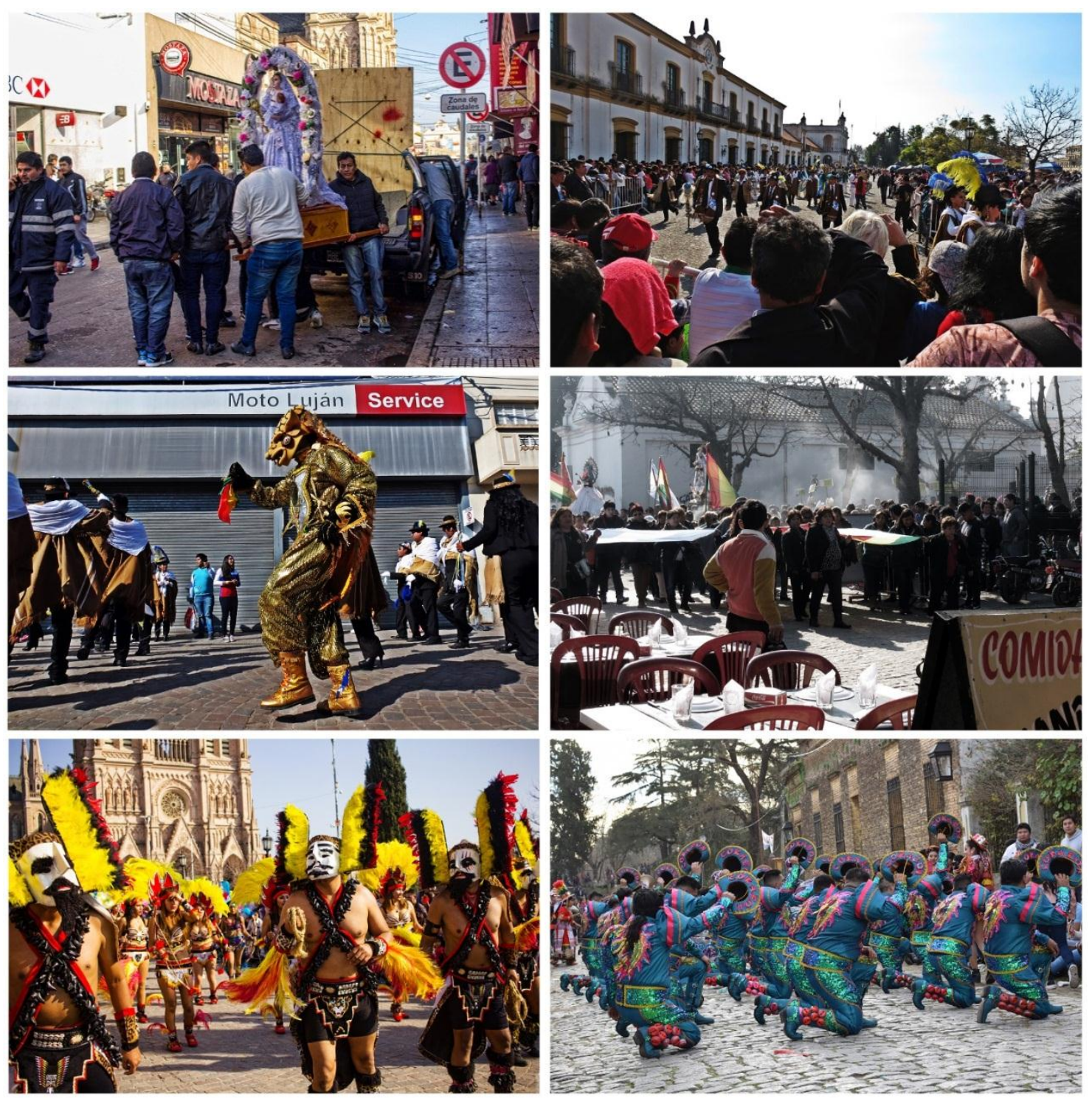

\section{Imágenes 22-27 Creación del paisaje híbrido}

Fotografías: Mauricio Martínez, Camila Bonaudo y Nicolás Álvarez

Lo anterior se comprende mejor a partir de la propuesta de Michel Foucault relativa a entender el espacio como la "relación que se establece entre cuerpos, objetos y palabras, entre imágenes, discursos, sujetos y cuerpos, entre palabras y gestos", en una "posibilidad infinita de emplazamientos" (1999, p. 432). De este modo, el estado híbrido de los espacios territoriales, emocionales, psicológicos o corporales donde se entrecruzan o se separan elementos que de algún modo modifican o transforman las identidades, pero donde además opera la memoria, se resignifica o se actualiza el pasado y se escribe el presente, tomando la forma de una heterotopía (Foucault, 1999). Así, pese a que la celebración en la que participamos y analizamos es materialmente localizable, los modos y posibilidades de ser, de habitar y nombrar el mundo, se ubican fuera de allí, en otro espacio. Por ello es importante insistir en la dimensión transcultural, no dialéctica y no binaria de este proceso 
de reterritorialización, y en las negociaciones que moldean este paisaje híbrido, heterotópico, que se abre como un campo de posibilidad de significaciones e identificaciones.

Los usos de la bandera wiphala en la celebración pueden resultar ilustrativos al respecto (ver imágenes 28-30). Pese a que la Nueva Constitución Política del Estado plurinacional boliviano, promulgada el 7 de febrero de 2009 en El Alto, la incluye entre los símbolos oficiales estatales (Artículo 6, parágrafo II), no fue izada junto a las banderas nacionales ni estuvo presente en los diferentes momentos de la primera parte de la celebración, centrada más en aspectos litúrgicos y políticos. Sin embargo, en la segunda parte, correspondiente al extenso desfile de las compañías de danza, fue un símbolo omnipresente; no solo se encontraba como distintivo en partes de los trajes de bailarines y músicos, sino que se ondeó en múltiples ocasiones.

Ahora bien, resulta interesante notar que la institucionalización de este símbolo en Bolivia no estuvo exenta de conflictos. Esto se debe especialmente a que la wiphala está vinculada específicamente al mundo andino (su origen se suele rastrear en los diseños de algunas chuspas $^{14}$ para la coca del período tiwanakota y en queros ${ }^{15}$ incaicos, como así también en representaciones de pinturas coloniales), y por ello no sería representativa de grupos étnicos no andinos como los guaraníes, los mojeños o los guarayos, por citar solo algunos. Pero más importante aún es su rechazo por parte de algunos sectores de la sociedad boliviana, que probablemente tiene que ver con el vínculo histórico de este símbolo con los movimientos indigenistas o con el simple hecho de que su oficialización fue impulsada por el gobierno de Evo Morales.

14 Término quechua (lit. "bolsa"), que refiere a un pequeño morral de lana o cuero de origen andino, utilizado para guardar y transportar coca para su uso en ciertos rituales o celebraciones.

15 Término quechua que designa a un tipo de vaso ceremonial andino de forma más o menos troncocónica, generalmente fabricado en madera, aunque también los hay de cerámica, plata u oro. Su uso, tanto en el período tiwanakota como en el incaico, estaba relacionado fundamentalmente con el consumo de chicha en contextos rituales. 

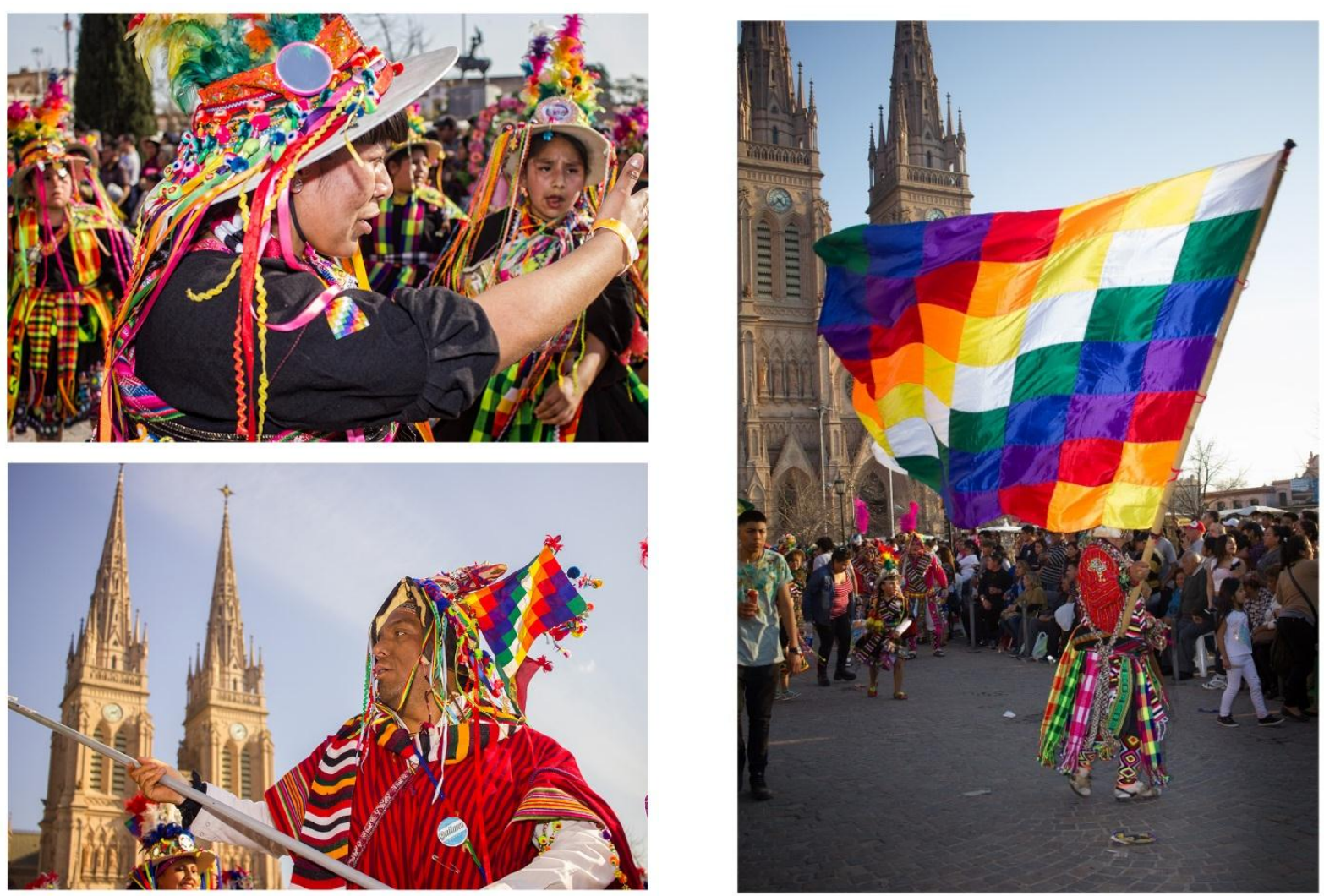

\section{Imágenes 28-30 La wiphala}

Fotografías: Mauricio Martínez

Al mismo tiempo, el uso de este símbolo se ha extendido en nuestro país en ámbitos muy variados. No solo es común ver flamear esta bandera en manifestaciones sociales o de índole más político, sino que incluso es posible advertir su presencia en actos escolares o en otras instituciones públicas. ${ }^{16}$ La significación atribuida en estos contextos trasciende su origen andino, pues se concibe como símbolo representante de los pueblos originarios americanos y, más aún, como expresión de la diversidad en general. De hecho, este atributo, relacionado sobre todo con su composición de colores, la acerca (en muchos casos físicamente) a la bandera LGBT, cuya presencia también ha transitado el espacio urbano en distintas marchas o manifestaciones asociadas a este colectivo o de otra naturaleza.

Los componentes plásticos, la multiplicidad de colores y su forma de romper con la linealidad y la horizontalidad de las banderas nacionales mediante la disposición de las

16 La Cámara de Diputados de la Provincia del Chaco, por ejemplo, sancionó la Ley N 6781 el 20 de abril de 2011 que reconoce "a la Bandera Indígena 'Wiphala', como emblema de los pueblos originarios de América", "hasta tanto un Congreso Indigenista defina una Bandera Indígena Argentina, que represente las comunidades aborígenes que habitan el suelo argentino" (MJDHN, 2015, p. 311). En muchas otras provincias existen ordenanzas, disposiciones o proyectos de ley similares. 
cuadrículas coloreadas que conforman diagonales, convierten a la wiphala en un símbolo propicio para la diversidad. Más que cualquier otro símbolo de los que circulan en la peregrinación, ella expresa el carácter híbrido de la celebración y de las identidades que se posicionan en ese tercer espacio. Así, este emblema se nos presenta como un geosímbolo, ${ }^{17}$ como uno de los soportes en el que se revela la hibridez, la heterotopía, de ese paisaje peregrino como escenario móvil. ${ }^{18}$ En este, se supera la coparticipación de las banderas nacionales, como así también de las advocaciones marianas patronas de ambos países y la delimitación de las identidades que conlleva, al integrar en un híbrido la dicotomía argentino/boliviano sin diluir las diferencias en una negociación no exenta de tensiones.

Otro aspecto transcultural del espacio en estudio es la densa textura del paisaje musical en el que se entretejen expresiones de orígenes y géneros diferentes. ${ }^{19}$ La música inunda hasta el último rincón del circuito y alrededores por donde transitan músicos y bailarines. Durante los breves intersticios que tienen lugar entre el final del desfile de una compañía y el comienzo del de otra se produce una cacofonía. Esta irrumpe en esa tendencia hacia el vacío, propia de estas manifestaciones, para sostener el correlato de la circularidad espacial con la del tiempo, tornándose en un signo disruptivo que denota tanto la espesura como las irregularidades del entramado híbrido que hace a la topografía de ese paisaje musical.

Es importante notar cómo inclusive las características tímbricas de estas expresiones musicales constituyen un soporte relevante para la conformación de la heterotopía. De este modo, independientemente del género o estilo de las músicas ejecutadas, los timbres de los instrumentos de bronce remiten directamente a la música militar y a las canciones patrias ${ }^{20}$

17 Aquí seguimos la definición clásica de Joël Bonnemaison, según la cual un geosímbolo es un "marcador espacial, un signo en el espacio que refleja y forja una identidad" (2004, p. 55). Sin embargo, utilizamos este concepto de modo más laxo, para pensar la celebración como un escenario móvil y reflexionar en torno a los elementos que, como en el caso de la wiphala, permiten el despliegue de un espacio heterotópico en el que se dirimen mecanismos de identificación híbridos, más contingentes y fluctuantes que los que se derivan de la noción de identidad fija que entraña la definición de este autor.

$18 \mathrm{Al}$ pensar el paisaje como escenario móvil, partimos de las afirmaciones de Henri Lefebvre acerca de que el espacio "no fue producido para ser leído y conceptualizado, sino para ser vivido por gentes con cuerpos y vidas en su propio contexto urbano" (2013, p. 194). De este modo, nuestra noción apunta a dar cuenta de ese lugar transitorio en el que se desarrollan las prácticas que responden a ciertas lógicas y ordenamientos del espacio, en el que se despliegan diferentes modos de representación.

19 Pudimos escuchar, por ejemplo, temas tan diversos como tonadas tupiceñas, cantos yungueños, o arreglos para las bandas de metal de melodías de la cumbia peruana, del pop latinoamericano, del reggaetón o del rock argentino, además de los abundantes ejemplos de música popular boliviana.

20 En otro trabajo hemos resaltado la preponderancia de las bandas de bronces en las fiestas populares y en las celebraciones religiosas tanto en Bolivia como en Argentina. En el caso boliviano, por ejemplo, la utilización de estos instrumentos tiene directa relación con la guerra del Chaco y fue creciendo en importancia en las décadas sucesivas. Su origen es indisociable de las bandas militares de la época republicana. Así, paradójicamente, la ejecución de diferentes melodías de carácter "folklórico" con una impronta tímbrica, no solo las despoja de su aparente relación intrínseca con los instrumentos ancestrales a partir de los que fueron creados (y cuyo carácter patrimonial es defendido decididamente por el Estado boliviano), sino que al mismo tiempo puede ligarlas a las canciones patrias o al propio himno nacional (Dawidiuk y Vogel, 2019). 
escuchadas en celebraciones de efemérides en el contexto escolar y en otros actos cívicos. En este sentido, podemos observar (y escuchar) que la trama transcultural de este paisaje se teje también a partir de aportes interdiscursivos que configuran esta simbología inmaterial que interpela las emociones y las sensibilidades de los sujetos-peregrinos.

Lo mismo ocurre con las estrategias transmediales (Toro, 2007) que podemos detectar en los trajes y máscaras (ver imágenes 31-34). Así, estos soportes no solo denotan la danza a la que normalmente se hallan vinculadas, sino que también cuentan historias de los personajes a los que refieren (el oso, el quirquincho, los diablos, los reyes morenos, los brujos, las chinas, etc.), articulándolas con diferentes niveles espaciales de pertenencia, como el nacional (las banderas boliviana y argentina, o el nombre bordado de las naciones), el regional (tejidos del altiplano, arte plumario del oriente boliviano, nombres de provincias o departamentos argentinos y bolivianos) y el local (bordados con nombres de ciudades o barrios de residencia en Argentina). Del mismo modo, la disposición espacial de algunas figuras coreográficas guarda relación con las tramas de algunos tejidos del altiplano boliviano.
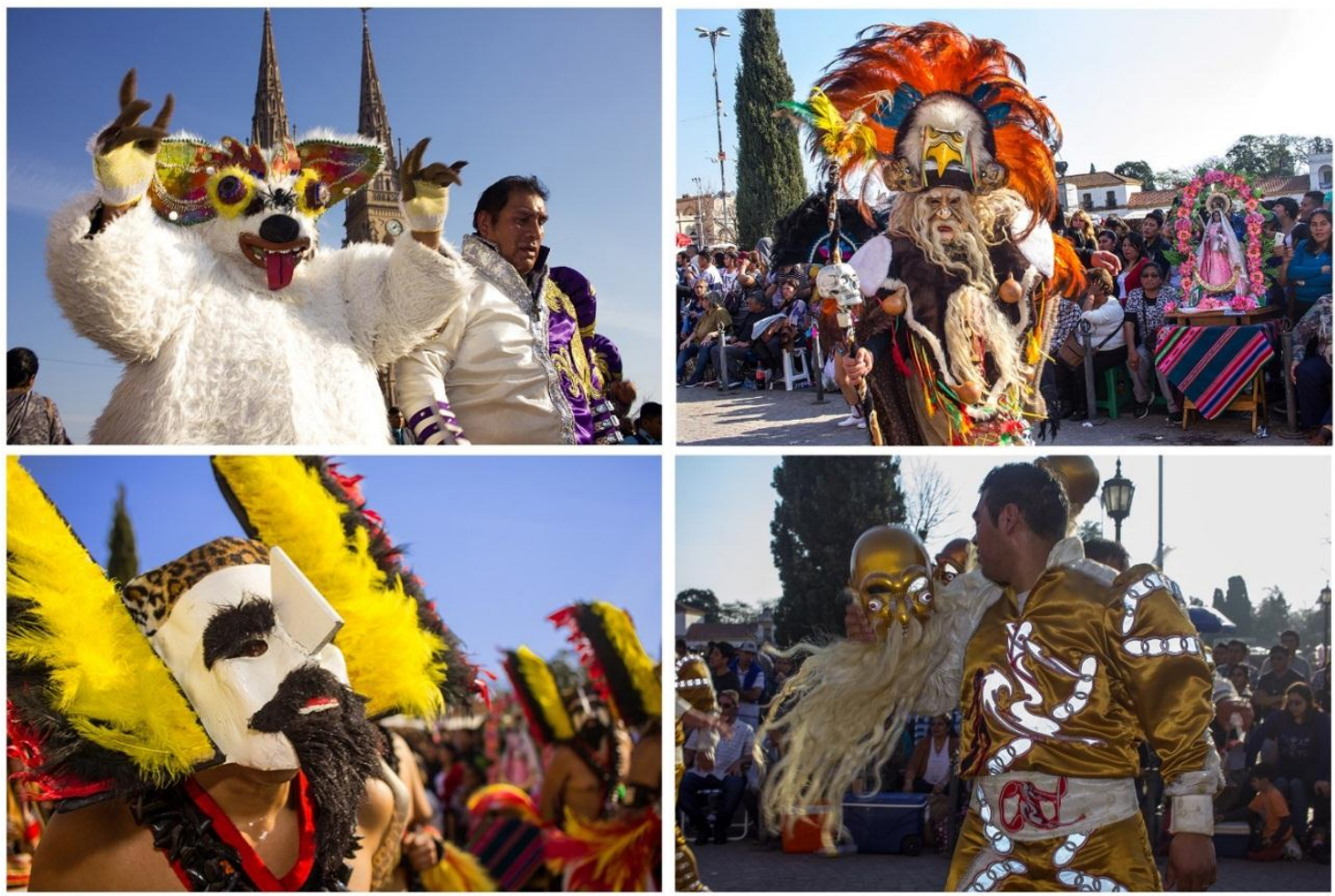

Imágenes 31-34 Personajes

Imagen 31 (arriba a la izquierda), el oso es un personaje popular que aparecen en danzas como la morenada y la diabladada. Surgió de la transformación del jukumari (oso andino) en un oso polar. Imagen 32 (arriba a la derecha), el brujo/abuelo es un personaje de la danza de los tobas. Es originaria del altiplano y representa a los pueblos del Oriente boliviano. Imagen 33 (abajo a la izquierda), máscara de aña, personaje gracioso vinculado al espíritu de los antepasados, originario del Chaco boliviano. Imagen 34, máscara de un caporal que representa a un esclavo negro.

Fotografías: Mauricio Martínez 
Por supuesto, todo esto se encuadra en un soporte más amplio, cuyo carácter espectacular suele ser interpretado como el aspecto central de esta celebración, tanto por los espectadores asistentes como por una gran cantidad de los participantes del colectivo boliviano: el despliegue de los cuerpos danzantes que ocupa la mayor parte de la festividad.

Las danzas practicadas, entre las que se destacan el caporal, el tinku, la morenada, tobas o la saya yungueña, entre otras, dan cuenta del proceso de desterritorialización y reterritorialización de la cultura, pues todas son originarias de Bolivia y poseen un marcado carácter regional o local. Así, muchos de los participantes expresan que su relación con las danzas tiene que ver esencialmente con una necesidad, con un deber de conservar la cultura o de mantener el sentimiento que los liga a Bolivia, pese a no conocer en profundidad su contenido simbólico o histórico y/o no haber nacido o visitado nunca ese país. Además de la enseñanza recibida por parte de instructores bolivianos o de otros que viajan al país vecino para formarse, muchos utilizan también recursos virtuales para el estudio de las danzas. Asimismo, es interesante notar que varias fraternidades, como en el caso de San Simón, poseen sedes en distintas ciudades de Bolivia y también en Argentina.
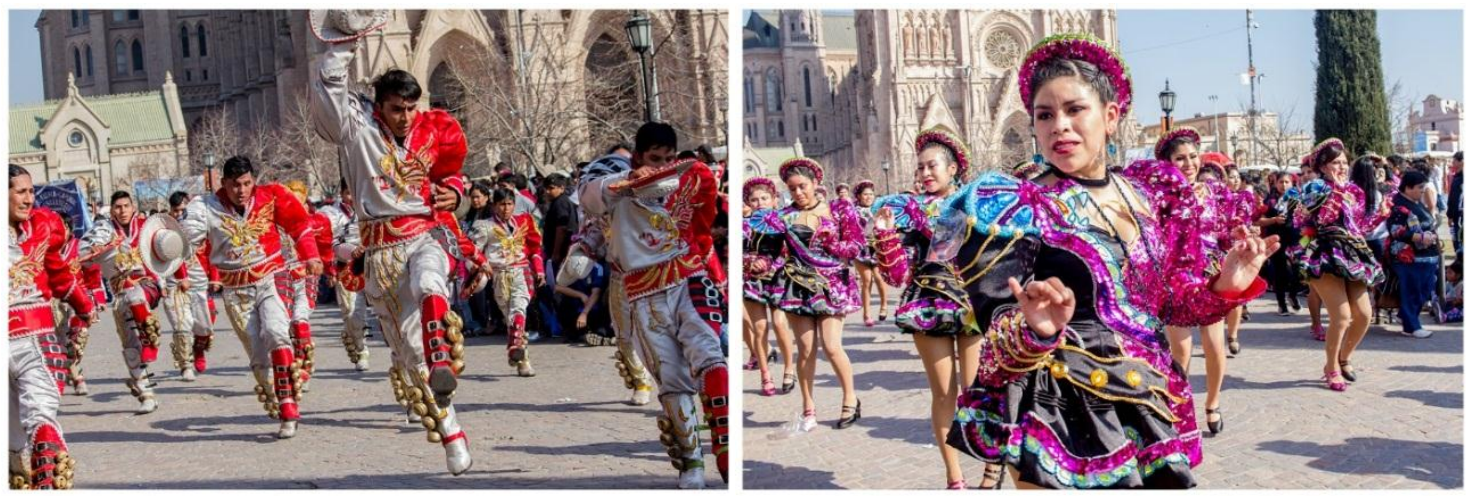

Imágenes 35-36 Expresiones de virilidad y sensualidad en el caporal

Fotografías: Mauricio Martínez

Por último, podemos afirmar que la fuerza del ritual dancístico radica fundamentalmente en su carácter performativo (Tambiah, 1985), pero también en sus facetas oréctica (Turner, 1999) y comunicativa (Gluckman, 1958), dimensiones que se integran para dar forma al paisaje híbrido y móvil. En el lenguaje kinésico de las danzas, en sintonía con las vestimentas, se marcan las diferencias entre la virilidad masculina y la sensualidad femenina (ver imágenes 35-36). Pero además de los hombres y las mujeres que tradicionalmente han formado parte de esta festividad, representantes de minorías como los gays, las travestis y los afrobolivianos, o sencillamente mujeres ocupando lugares típicamente masculinos, marcan con naturalidad su impronta (ver imágenes 37-41). Tampoco faltan niños y niñas, o incluso sacerdotes y monjas, en ese despliegue heterogéneo de los cuerpos que bailan. Así, todas las figuras danzantes esculpen con su movimiento el paisaje-peregrino híbrido, heterotópico, en el que se expresan sexualidades 
condenadas por la propia Iglesia católica, como también danzas que aluden a rituales paganos, y se manifiestan comportamientos o actitudes profanas que parecieran entrar en abierta contradicción con lo sagrado, pero que se conjugan con muestras abiertas de devoción hacia la Mamita de Copacabana y demás santos en este escenario móvil.
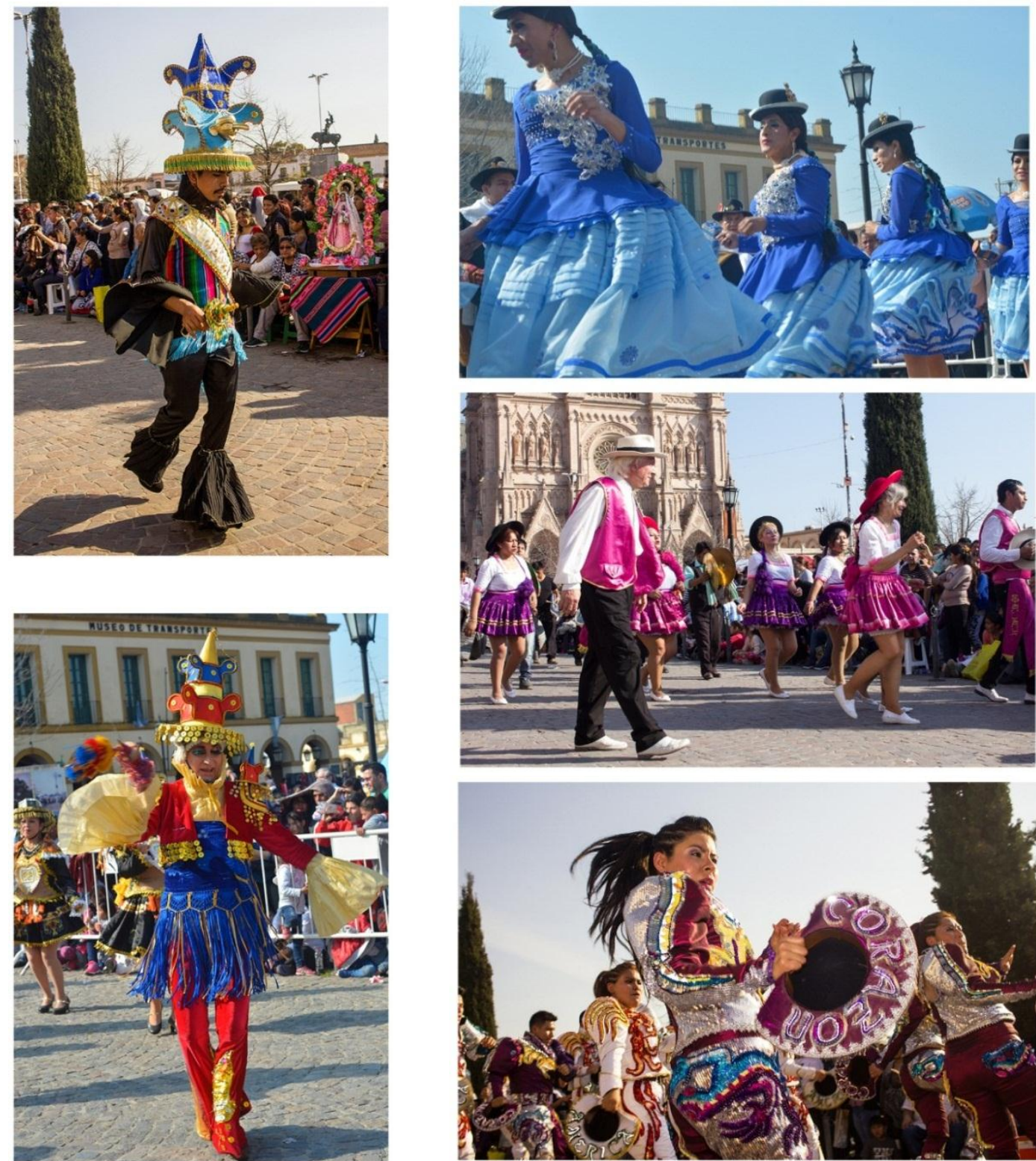

\section{Imágenes 37-41 Cuerpos diversos, cuerpos híbridos}

Imagen 37 y 38 (izquierda), los cuerpos masculinos de la kullawada despliegan movimientos asociados con lo femenino. Imagen 39 (arriba a la derecha), las trans participan en la morenada desde hace décadas. Imagen 40 (derecha, centro), un sacerdote y una monja abandonan los hábitos que vestían en la ceremonia litúrgica para unirse a una compañía de danza. Imagen 41, las "machas" del caporal desempeñan el mismo rol que los hombres en la danza.

Fotografías: Mauricio Martínez y Camila Bonaudo 


\section{A modo de conclusión}

Partiendo de nuestra hipótesis sobre la hibridez cultural, que se sirve precisamente para resaltar la diferencia sin homogeneizar ni adaptar la cultura, nos hemos focalizado en los modos en que el colectivo boliviano desarrolla una serie de estrategias identitarias transculturales y transmediales en el escenario móvil de la peregrinación en cuestión. Asimismo, al pensarlas en el marco de una negociación que tiene lugar en un tercer espacio, en el cual la convicción de los sujetos-peregrinos de la extranjeridad -como signo identitario de la diferencia- no se dirime en la bolivianidad como una expresión transparente, homogénea o cerrada de esos cuerpos-territorio.

En este sentido, los modos en que se articulan y despliegan discursos, símbolos y prácticas desterritorializados y reterritorializados en este espacio-movimiento heterotópico, no solo rebasan los límites de la concepción tradicional de una peregrinación, sino que nos exhortan a reflexionar sobre las limitaciones de su caracterización como un fenómeno esencialmente migrante. Lo mismo ocurre con la percepción de esta celebración como una apropiación del espacio público, cuya intervención colma de formas creativas, generadoras de una heterotopía, que exceden a dicha determinación de índole más instrumental.

\section{Referencias bibliográficas}

Anderson, B. (2007). Comunidades imaginadas. Reflexiones sobre el origen y la difusión del nacionalismo. México: FCE.

Appadurai, A. (2001). La modernidad desbordada. Dimensiones culturales de la globalización. Buenos Aires: FCE.

Assmann, J. (2008). Religión y memoria cultural. Diez estudios. Buenos Aires: Lilmod.

Bhabha, H. (2013). Nuevas minorías, nuevos derechos. Notas sobre cosmopolitismos vernáculos. Buenos Aires: Siglo XXI.

Bonnemaison, J. (2004). La géographie culturelle. París: Éditions du CTHS.

Casanello, C. (2016). Migración, identidad y memoria. Los bolivianos en la Argentina (1970-2010). Bernal: Universidad Nacional de Quilmes.

Dawidiuk, C. y Vogel, C. (2019). La peregrinación de la Virgen de Copacabana en Luján. Aproximaciones a la relación entre música, danza, identidad y espacialidad. En C. Carballo y F. Flores (Eds.), Geografías de lo sagrado en la contemporaneidad (pp. 155-158). Bernal: Universidad Nacional de Quilmes.

Derrida, J. (2004). Autoinmunidad: suicidios simbólicos y reales. En G. Borradori, La filosofia en una época de terror. Diálogos con Jürgen Habermas y Jacques Derrida (pp. 131-196). Buenos Aires: Taurus. 
Derrida, J. y Dufourmantelle, A. (2000). La hospitalidad. Buenos Aires: Ediciones de la Flor.

Douglas, M. (2007). Pureza y peligro. Un análisis de los conceptos de contaminación y tabú. Buenos Aires: Nueva Visión.

Elias, N. (1970). Sociología fundamental. Barcelona: Gedisa.

Figueroa-Dreher, S., Dreher, J. y Soeffner, H. (2011). Construcción de identidades en sociedades pluralistas. Procesos de construcción de lo "extraño" y lo "propio" en la Argentina. En S. Figueroa-Dreher, J. Dreher y H. Soeffner (Eds.), Construcciones de identidad y simbolismo colectivo en Argentina (pp. 11-47). Buenos Aires: Prometeo.

Flores, F. (2012). Luján como hierópolis: del relato espacial al lugar religioso. Revista Universitaria de Geografia, 21(1), 137-158.

Foucault, M. (1999). Espacios diferentes. En Obras Esenciales, Vol. III (pp. 431-441). Barcelona: Paidós.

García Canclini, N. (1989). Culturas híbridas. Estrategias para entrar y salir de la modernidad. México: Grijalbo.

Gluckman, M. (1958) Analysis of a Social Situation in Modern Zululand. Manchester: Manchester University Press.

Halbwachs, M. (2004). Los marcos sociales de la memoria. Barcelona: Anthropos.

Lara Barrientos, M. y Córdova, X. (2011). Fiesta urbana en los Andes. Experiencias y discursos en el Carnaval de Oruro. Oruro: Latinas Ediciones.

Lefebvre, H. (2013). La producción del espacio. Madrid: Capitán Swing.

Lindón, A. (2017). La ciudad movimiento: cotidianidades, afectividades corporizadas y redes topológicas. InMediaciones de la Comunicación, 12(1), 107-126.

Massey, D. (1999). Imaginar la globalización: las geometrías del poder del tiempo-espacio. En A. Albert y N. Berroch, Doreen Massey. Un sentido global del lugar (pp. 130155). Barcelona: Icaria.

Ministerio de Justicia y Derechos Humanos de la Nación (MJDHN) (2015). Derechos de los pueblos indígenas en la Argentina, una compilación. Buenos Aires: MJDHN.

Ortiz, F. (1983). Contrapunteo cubano del tabaco y el azúcar. Habana: Editorial de Ciencias Sociales.

Ortiz, R. (2005). Otro territorio. Ensayos sobre el mundo contemporáneo. Bernal: Universidad Nacional de Quilmes.

Revollo Fernández, A. (2015). Apuntes del "Carnaval Sagrado” de Oruro. Obra Maestra del Patrimonio Oral e Intangible de la Humanidad. Oruro: Latinas Ediciones.

Ricoeur, P. (1996). Sí mismo como otro. Madrid: Siglo XXI. 
Rosendahl, Z. (2009). Hierópolis y procesiones: lo sagrado y el espacio. En C. Carballo (Ed.), Cultura, territorios y prácticas religiosas (pp. 43-56). Buenos Aires: Prometeo.

Smietniasky, S. (2012). El estudio de las instituciones del gobierno colonial. Una aproximación etnográfica al juicio de residencia como ritual. Corpus. Archivos Virtuales de la Alteridad Americana, 2(1), 1-32.

Tambiah, S. (1985) A performative approach to ritual. En S. Tambiah (Ed.) Culture, Thought and Social Action (pp. 123-166). Cambridge: Harvard University Press.

Toro, A. (2005). Pasajes-heterotopías-transculturalidad: estrategias de hibridación en las literaturas latino/americanas: un acercamiento teórico. En B. Mertz-Baumgartner y E. Pfeiffer (Eds.), Aves de paso: autores latinoamericanos entre exilio y transculturación (pp. 19-28). Frankfurt am Main: Vervuert.

Toro, A. (2007). Dispositivos transmediales, representación y anti-representación. Frida Kahlo: transpictorialidad-transmedialidad. Comunicación, 5, 65-23.

Toro, A. (2014). Transmedialidad y transculturalidad. Un modelo. En B. Baczyńska y M. Krupa (Eds.), Entre artes, culturas y tiempos. Poesía y teatro hispánicos (pp. 1433). Wrocław: Wydawnictwo Uniwersytetu Wrocławskiego.

Turner, V. (1988). El proceso ritual. Estructura y antiestructura. Madrid: Taurus.

Turner, V. (1999). La selva de los símbolos. Aspectos del ritual ndembu. México: Siglo XXI. 